\title{
Okresné a krajské pedagogické zbory - nástroj realizácie a koordinácie vedeckého výskumu v pedagogickej praxi
}

\author{
MARTIN GABČO \\ CVTI - Múzeum školstva a pedagogiky, Bratislava
}

\begin{abstract}
District and regional pedagogical groups - an instrument for implementation and coordination of scientific research in pedagogical practice
\end{abstract}

Abstract: In submitted contribution there are analysed the ways of organizing and functioning of district and regional pedagogical groups in the period between years $1947-1950$. The intention of that groups was the centralisation of pedagogical research; performed not only by experts, but mainly by teachers from various schools, too. These organisations had been functioned as part of the newborn State Pedagogical Institute in Bratislava. Teachers from praxis, by their daily connection with teaching practice, were able to search and study existing pedagogical problems. Professionals from State Pedagogical Institute received materials - results from local researches - and evaluated and prepared them to final form for publishing. Duty of the groups was to inform the center in Bratislava about all implemented activities. Their activities also included professional lectures on pedagogy - by this way was the partial development of pedagogical theory garanted. On the other side, all the activities of district and regional pedagogical groups were strongly deformed by ideological pressure.

Keywords: State pedagogical institute, district and regional pedagogical groups, pedagogical research, teachers, education problems.

DOI: https://doi.org/10.24040/ahn.2021.24.02.134-159

V turbulentnej atmosfére nástupu a postupnej mocenskej konsolidácie komunistického režimu prebiehalo budovanie a dotváranie štruktúry významnej pedagogickej ustanovizne s celoslovenskou pôsobnost'ou Štátneho pedagogického ústavu (d’alej ŠPÚ). Základná úloha tejto inštitúcie od jej zriadenia dňa 25. februára 1947 až do súčasnosti spočíva v úsilí o skvalitnenie teoretickej (a následne aj praktickej) úrovne slovenskej pedagogiky prostredníctvom realizácie spektra výskumných úloh. ${ }^{1}$ Konkrétne môžeme hovorit' o prácach na výskume, zostavovaní a posudzovaní učebných osnov, učebníc, trojrozmerných učebných

\footnotetext{
1 Dňa 25. februára 1947 Slovenská národná rada náplň činnosti ŠPÚ schválila výnosom č. 32/47. Pozri viac: FERLIKOVÁ, Klára (ed.): Pamätnica pri príležitosti 60. výročia založenia Štátneho pedagogického ústavu. Bratislava: Štátny pedagogický ústav, 2007, s. 30.
} 
pomôcok alebo školských filmov v závislosti od požiadaviek, kladených na edukačný obsah jednotlivých vyučovacích stupňov. ${ }^{2}$

Nezanedbatel'ným aspektom pôsobenia Štátneho pedagogického ústavu v období po jeho založení sa stali tzv. pedagogické zbory, organizované na okresnej a od roku 1949 aj na krajskej úrovni. V zásade ich je možné definovat' ako inštitúcie, ktoré pod gesciou ŠPÚ organizovali a uskutočňovali pedagogický výskum na poli jednotlivých okresov a prostredníctvom prednášok alebo akcií podobnej proveniencie pokračovali v aktívnom odbornom vzdelávaní svojich členov na poli vyučovacích predmetov, ktoré na školách konkrétne vyučovali. Výstižnú definíciu tohto fenoménu sformuloval vtedajší pracovník I. odboru ŠPÚ Ján Ededy na stránkach textu Sústredenie pedagogickej práce v okresných pedagogických sboroch nasledovne: „,[...] bádatel'ská práca Štátneho pedagogického ústavu, ako odborného fóra pre plánovanie v oblasti pedagogickej, nemôže sa obmedzovat' len na prácu v samom ústave, ale musí byt' budovaná na širokej skúsenosti pedagogických pracovníkov po školách - od materských až po vysoké - a ich skúsenosti overovat', spracúvat' a usmerňovat'. K tomuto ciel'u založil si Štátny pedagogický ústav svoje pracovné orgány, okresné pedagogické sbory. V nich organizuje pedagogických pracovníkov a pedagogickú prácu po odborných pracovných komisiách. Okresné pedagogické sbory sú dôležitými výkonnými a súčasne aj iniciatívnymi orgánmi Štátneho pedagogického ústavu, ktorý zase v pomere $k$ ním je ústredným, bádatel'ským, hodnotiacim a poradným telesom. "3 Vzt'ah okresných pedagogických zborov (d'alej OPS; podl'a súdobého pravopisu „Okresný pedagogický sbor“) k centrálnemu orgánu - ŠPÚ presne vymedzil organizačný poriadok OPS na Slovensku. Už v podobe návrhu organizačný poriadok OPS definoval ako pracovné orgány ŠPÚ v Bratislave, pričom predsedovia jednotlivých pedagogických zborov zastupovali OPS smerom k ŠPÚ s povinnost'ou riadit' sa v otázkach fungovania OPS pokynmi ústavu. ${ }^{4}$

Čo sa týka stavu spracovania problematiky OPS, v prvom rade sa chcem rozhodne zmienit' o zborníku, v ktorom sú publikované príspevky

\footnotetext{
2 Základné úlohy novovzniknutej inštitúcie spočívali vo výskume organizácie školského systému, skúmaní učebníc, resp. učebných pomôcok, budovaní ústrednej pedagogickej knižnice a v kooperácii so zahraničnými pedagogickými výskumnými inštitúciami. Pozri viac: Desat' rokov Výskumného ústavu pedagogického v Bratislave. In: Jednotná škola, roč. XII., č. 4, 1957, s. 386 - 387.

${ }^{3}$ EDEDY, Ján: Sústredenie pedagogickej práce v okresných pedagogických sboroch. In: Zvesti Štátneho pedagogického ústavu v Bratislave. Príloha časopisu Jednotná škola. Bratislava : Štátne pedagogické nakladatel'stvo, I. polrok 1948, s. 3.

${ }^{4}$ Návrh na organizačný poriadok okresných pedagogických zborov (OPS) na Slovensku. In: Zvesti Štátneho pedagogického ústavu v Bratislave. Príloha časopisu Jednotná škola. Bratislava : Štátne pedagogické nakladatel'stvo, II. štvrt'rok 1949, s. 22.
} 
zo seminára, konaného pri príležitosti 50. výročia založenia prvého dobrovol'ného pedagogického zboru učitel'ov na Slovensku v Prešove (28. a 29. október 1997). ${ }^{5}$ V rámci palety v zborníku publikovaných príspevkov je vzhl'adom na nami riešenú tému najobsažnejším text Ivana Pavlova, nesúci názov Náčrt histórie idey d'alšieho vzdelávania učitel'ov na Sloven$s k u$. Fenomén pedagogických zborov autor sleduje v kontexte inštitucionalizovaných snáh o zvyšovanie vzdelanostnej úrovne slovenských učitel'ov v období od druhej polovice štyridsiatych až do začiatku devät'desiatych rokov 20. storočia. Na skutočnost', že vznik OPS predstavoval začiatok prvej etapy vývoja postgraduálneho vzdelávania učitel'ov, upozornil v 70. rokoch v štúdii $Z$ histórie okresných pedagogických stredísk na Slovensku vedecký pracovník Výskumného ústavu pedagogického (v rokoch 1987 - 1988 pôsobil ako riaditel' tejto inštitúcie) Matej Beňo. 6 Štúdia predstavuje najkomplexnejšie spracovaný prehl'ad vzniku a fungovania okresných pedagogických zborov, ked’že v texte nachádzame solídne a podrobne spracovaný obraz ciel'ov, organizačnej štruktúry, okolností vzniku a foriem činnosti OPS. Základné informácie sa nachádzajú aj v rámci hesla „Okresné pedagogické zbory“ na stránkach Pedagogickej encyklopédie Slovenska. ${ }^{7}$ Taktiež nemožno obíst' pamätnicu, ktorá bola v roku 2007 vydaná pri príležitosti 60. výročia založenia Štátneho pedagogického ústavu. Obsahuje totiž fakty o okolnostiach založenia prvého OPS v Prešove (dňa 30. júna 1947) a presný zoznam OPS založených do konca roka 1947.8

Pedagogické zbory vo vzt'ahu k ŠPÚ existovali ako jeho externé súčasti. ${ }^{9}$ Čo sa týka typológie pedagogických zborov, v období chronologicky vymedzenom rokmi 1947 - 1950/1954 môžeme hovorit' o ich dvoch formách: okresných a krajských pedagogických zboroch. Z organizačného hl'adiska pedagogické zbory patrili k školským inšpektorátom, zatial' čo v roku 1950 došlo k ich zaradeniu pod gesciu okresných národných výborov (ONV). ${ }^{10}$ Táto zmena predstavuje predel v ich fungovaní a uzatvára tým dobre sledovatel'nú fázu formovania a „rozbehu“ OPS na

\footnotetext{
5 PAVLOV, Ivan (ed.): 50 rokov venovaných d'alšiemu vzdelávaniu slovenského učitel'stva : zborník príspevkov zo seminára z príležitosti 50. výročia založenia prvého dobrovol'ného pedagogického zboru učitel'ov na Slovensku v Prešove (28. a 29. október 1997). Prešov : Metodické centrum, 1998. $202 \mathrm{~s}$.

${ }^{6}$ BEŇO, Matej: Z histórie okresných pedagogických stredísk na Slovensku. In: Jednotná škola, roč. 30, č. 4, apríl 1978, s. 354.

${ }^{7}$ Okresné pedagogické zbory. In: Pedagogická encyklopédia Slovenska. 1 A - O. Bratislava : VEDA, 1984, s. 661.

${ }^{8}$ FERLIKOVÁ, K. (ed.): Pamätnica pri príležitosti 60. výročia, s. 34.

${ }^{9}$ PAVLOV, Ivan: Náčrt histórie idey d'alšieho vzdelávania učitel'ov na Slovensku. In: PAVLOV, I. (ed.): 50 rokov venovaných d'alšiemu vzdelávaniu, s. 60.

${ }^{10}$ PAVLOV, I.: Náčrt histórie idey d’alšieho vzdelávania, s. 61.
} 
Slovensku. Matej Beňo priradenie OPS pod správu ONV taktiež označuje za medzník, začínajúci druhú etapu vývoja sústavy d’alšieho vzdelávania učitel'ov, pričom túto druhú fázu označil vzhl'adom na vývin OPS za jednoznačne úspešnú: „Jednou z najcharakteristickejších čŕt tohto obdobia je rýchly kvantitatívny rozvoj OPS, ale aj rozvoj nových foriem práce. ${ }^{11} \mathrm{Je}$ taktiež dôležité venovat' pozornost' skutočnosti, že v období od 4. decembra 1949 do 20. marca 1950 došlo k transformácii dvojstupňovej štruktúry OPS - ŠPÚ na trojstupňovú, pretože ŠPÚ založil podl'a vzoru z Čiech a Moravy novú organizačnú jednotku - Krajský pedagogický zbor (d'alej KPS). ${ }^{12}$ KPS smerom $\mathrm{k}$ OPS primárne fungoval v pozícii koordinačného a kontrolného orgánu. ${ }^{13}$

Uvedená heuristická základňa oboznamuje s klúčovými faktami o fungovaní OPS a spektre nimi realizovaných činností. V ich kontexte ma podrobnejšie zaujíma najmä vzt’ah ŠPÚ a pedagogických zborov. Akými konkrétnymi spôsobmi ŠPÚ usmerňoval činnost' pedagógov na okresnej a krajskej úrovni? Prebiehala existujúca spolupráca bezproblémovo alebo, naopak, prekážali vyskytujúce sa problémy realizácii vytýčených ciel'ov a zámerov? Z chronologického hl'adiska sa pri hl'adaní odpovedí na uvedené otázky zameriam na už spomenuté úvodné obdobie rokov 1947 - 1950, ked' dochádzalo k formovaniu organizačného, odborného a personálneho zázemia jednotlivých pedagogických zborov.

Hoci obdobie vymedzené rokmi 1947 - 1950 predstavuje relatívne krátky časový úsek, dostupné správy o fungovaní OPS dokumentujú éru „rozletu“ slovenských pedagógov, lebo mnohí z nich aktívne participovali na úsilí ŠPÚ o uskutočňovanie odborného výskumu vzdelávacieho systému a o zdokonal'ovanie, resp. vydávanie nových učebníc, učebných

\footnotetext{
${ }^{11}$ BEŇO, M.: Z histórie okresných pedagogických stredísk na Slovensku, s. 360.

12 Prvý KPS bol založený dňa 4. decembra 1949 v krajskom meste Banská Bystrica, nasledovali d'alšie krajské mestá: Prešov (17. január 1950), Žilina (15. február 1950), Košice (16. február 1950), Bratislava (18. marec 1950) a Nitra (20. marec 1950). Pozri viac: Založili sme krajské pedagogické sbory. In: Zvesti Štátneho pedagogického ústavu v Bratislave. Príloha časopisu Jednotná škola. Bratislava : Štátne pedagogické nakladatel'stvo, I. štvrt'rok 1950, s. 11.

13 „Po poldruharočnej úspešnej činnosti okresných pedagogických sborov pristupujeme k d'alšej úlohe nášho pedagogického života, k zakladaniu krajských pedagogických sborov. Doterajšia prax s okresnými pedagogickými sbormi vyžaduje stále užšej spolupráce a vzájomnej pomoci susedných zborov. Túto prácu budú vykonávat' krajské pedagogické sbory. Budú koordinovat' činnost' okresných pedagogických sborov, pôsobit' ako ich poradňa $v$ školskej praxi a starat'sa o výmenu prednášatel'ov v kraji. Krajské pedagogické sbory budú tiež iniciatívnymi a kontrolnými orgánmi. V̌̌etky OPS budú svoju prácu plánovat', organizovat' a prehlbovat' z iniciatívy KPS, a zasa KPS budú podávat' iniciatívne návrhy za celý kraj ŠPÚ. KPS budú tiež kontrolovat' hospodárenie a prácu v okresných pedagogických sboroch, aby sa konala v intenciách Štátneho pedagogického ústavu. "Zakladáme krajské pedagogické sbory. In: Zvesti Štátneho pedagogického ústavu v Bratislave. Príloha časopisu Jednotná škola. Bratislava : Štátne pedagogické nakladatel’stvo, III. - IV. štvrt'rok 1949, s. 33.
} 
osnov, plánov a pomôcok. V doteraz vydanej spisbe nachádzame historický obraz snáh odborných pracovníkov ŠPÚ zapojit’ do procesu realizácie úloh ústavu pedagogickú verejnost'. ${ }^{14}$ Je však zaujímavé sledovat' spektrum konkrétnych metód, ktoré ŠPÚ využíval na usmernenie činnosti jednotlivých pedagogických zborov so zámerom plánovat’ a náležite zjednocovat' činnost' týchto jednotiek. Pri napĺňaní takto sformulovanej výskumnej úlohy som odpovede mohol hl'adat'v existujúcich zdrojoch písomnej proveniencie. Komunikácia ŠPÚ s členskou základňou pedagogických zborov je dostupná vd’aka Zvestiam Štátneho pedagogického ústavu v Bratislave (d'alej Zvesti ŠPÚ) - prílohy časopisu pre otázky pedagogickej teórie, psychológie a praxe Jednotná škola. Zvesti ŠPÚ vyšli v priebehu rokov 1948 - 1950 vo forme siedmich zošitov. ${ }^{15}$ Obsah týchto príloh pozostával z textov odborných pracovníkov ŠPÚ (Ján Ededy, L'udovít Bakoš, Rudo Moric, Štefan Palúch a pod.), ktorí takýmto spôsobom učitel'ov, združených v pedagogických zboroch, odborne usmerňovali pri riešení vytýčených výskumných úloh. ${ }^{16}$ Okrem toho boli na stránkach Zvestí ŠPÚ pravidelne uverejňované správy o činnosti jednotlivých pedagogických zborov a inštrukcie alebo zadania výskumných úloh s návodmi na ich praktické riešenie. Celkovo ide o bohatý prameň nielen $\mathrm{v}$ rovine konkrétnych pokynov zo strany ŠPÚ smerom k pedagogickým zborom ${ }^{17}$, ale prostredníctvom neho sa mnoho dozvedáme aj o výsledkoch iniciatívy členskej základne OPS (správy o besedách, konferenciách, mimoškolskej činnosti a pod.). ${ }^{18}$ Okrem Zvestí ŠPÚ je možné čerpat'

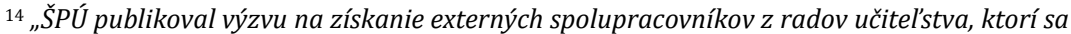
mali spolupodiel'at' na tvorbe nových učebných osnov, učebníc, metodík vyučovacích predmetov. Z celého Slovenska sa prihlásilo viac ako 300 učitel'ov, ktorí sa zúčastňovali tejto plodnej práce. Za pomoci OPZ (Okresných pedagogických zborov - pozn. M. G.), komisií i externých pracovníkov pracoval ústav najprv nad novými učebnými osnovami, koordinoval ich prácu. " PAVLOV, I.: Náčrt histórie idey d’alšieho vzdelávania, s. 61.

15 Desat' rokov Výskumného ústavu pedagogického v Bratislave, s. 391.

16 Týmto spôsobom boli učitelia z OPS oboznamovaní s výskumnými okruhmi, pedagogickou teóriou potrebnou pre úspešné riešenie vytýčených úloh a pod. Pozri: EDEDY, Ján: Sústredenie pedagogickej práce v okresných pedagogických sboroch. In: Zvesti Štátneho pedagogického ústavu v Bratislave. Príloha časopisu Jednotná škola. Bratislava : Štátne pedagogické nakladatel'stvo, I. polrok 1948, s. 2 - 15.; BAKOŠ, L’udovít: Poznámky k technickej stránke vedeckej práce. In: Zvesti Štátneho pedagogického ústavu v Bratislave. Príloha časopisu Jednotná škola. Bratislava : Štátne pedagogické nakladatel'stvo, II. polrok 1948.; MORIC, Rudolf: Úlohy filmových referentov pri OPS. In: Zvesti Štátneho pedagogického ústavu v Bratislave. Príloha časopisu Jednotná škola. Bratislava : Štátne pedagogické nakladatel'stvo, II. štvrt'rok 1949, s. 17 - 18.; PALÚCH, Štefan: Z výchovnej problematiky na odborných školách. In: Zvesti Štátneho pedagogického ústavu v Bratislave. Príloha časopisu Jednotná škola. Bratislava : Štátne pedagogické nakladatel'stvo, II. štvrt'rok 1950, s. 17 - 20.

17 Pozri rubriku „Zprávy“ a „Obežníky ŠPÚ“ vo Zvestiach ŠPÚ.

${ }^{18}$ Zvesti ŠPÚ obsahovali rubriky „Zo života okresných pedagogických zborov“ a „Plánovanie po okresných pedagogických sboroch“, v rámci ktorých boli uverejňované aktuality z činnosti
} 
z periodík Jednotná škola a Učitel'ské noviny. Uspokojivá bilancia činnosti OPS a KPS v rokoch 1947 - 1950 je podl'a mňa len t’ažko predstavitel'ná bez štúdia síce stručnej, ale o to obsažnejšej správy zaoberajúcej sa okresnými a krajskými pedagogickými zbormi, ktorá bola pripravená na 15. gremiálnu poradu PŠVU zo dňa 8. decembra $1950 .{ }^{19}$ Tento dvojstranový dokument obsahuje presné údaje o počte založených OPS, ich organizovaní, formách vyvíjanej činnosti a o raste počtu pedagogických zborov podl'a konkrétnych školských rokov. Taktiež sa z neho dozvedáme zaujímavé fakty týkajúce sa už spomenutej reorganizácie OPS a KPS, datovanej k 9. novembru 1950.20

Vzájomné fungovanie pedagogických zborov a ústredia prirodzene determinovala vnútorná štruktúra týchto orgánov a podmienky, resp. spôsob ich sformovania. Založenie OPS realizoval ŠPÚ s pomocou školských inšpektorov, ktorí organizovali nábor pedagogických pracovníkov. Proces etablovania OPS výstižne charakterizuje stat' „Z činnosti OPS na Slovensku“ publikovaná vo Zvestiach Štátneho pedagogického ústavu $v$ Bratislave z I. polroka 1948. Nakol'ko ide o zásadnú pasáž, dovolím si ju doslovne citovat': „Činnost' OPS na Slovensku datuje sa od decembra 1947, ked' ŠPÚ v Bratislave na oblastných konferenciách oboznámil škol. inšpektorov o zameraní práce ŠPÚ v Bratislave a dal podnet k zakladaniu OPS. Vyjmúc inšpektorátov, kde si založili OPS ešte na jar a z jesene 1947, bezprostredne po založení samého ŠPÚ v Bratislave, početnejšie zakladanie OPS začalo iba koncom roku 1947. Obyčajne to začínalo s prípravným výborom. Ked'však inšpektori učitel'stvo oboznámili s ciel'om OPS a ich organizačnými štatútmi, hned' svolávali plenárne schôdzky prihlásených spolupracovníkov - učitel'ov a profesorov a z prihlásených školských pracovníkov konštituoval sa OPS, výkonný orgán ŠPÚ. Podl'a počtu aktívnych spolupracovníkov vytýčili si OPS pracovné úlohy pre svoje odborné komisie, $v$ ktorých je t’ažisko práce OPS. “21 Uvedený citát okrem popisu okolností

jednotlivých OPS (počet konferencií, účast' na výskumoch - učebnice alebo osnovy, záväzky, riešené témy a pod.).

${ }^{19}$ Slovenský národný archív (d’alej SNA), fond Povereníctvo školstva, Kolégium povereníctva. 1950. Gremiálne porady, i. č. 435 - 447. Kr. č. 177. Okresné a krajské pedagogické sbory. Referát priložený k materiálu týkajúcemu sa XV. gremiálnej porady PŠVU zo dňa 8. decembra 1950.

${ }^{20}$ „Výnos o zriadení OPS a KPS bol uverejnený v Sbierke obežníkov pre KNV (Krajský národný výbor - pozn. M. G.) zo dňa 9. XI. 1950, č. 82. Podl'a tohto výnosu prebieha reorganizácia OPS a KPS. I. odbor PŠVU vyžiada urýchlené podanie zpráv o priebehu reorganizácie OPS a KPS." SNA, fond Povereníctvo školstva, Kolégium povereníctva. 1950. Gremiálne porady, i. č. 435 - 447. Kr. č. 177. Okresné a krajské pedagogické sbory. Referát priložený k materiálu týkajúcemu sa XV. gremiálnej porady PŠVU zo dňa 8. decembra 1950, s. 2.

${ }^{21} \mathrm{Z}$ činnosti OPS na Slovensku. In: Zvesti Štátneho pedagogického ústavu v Bratislave. Príloha časopisu Jednotná škola. Bratislava : Štátne pedagogické nakladatel'stvo, I. polrok 1948, s. $20-21$. 
formovania OPS poukazuje aj na organizačné formy zastrešujúce tých učitel'ov, ktorí boli ochotní zapojit' sa do rozvíjania slovenskej pedagogiky pod taktovkou ŠPÚ. V prvom rade išlo o prípravné výbory, zatial' čo po definitívnom sformovaní jednotlivých OPS kl'účovú úlohu v ich fungovaní zastávali pedagogické okrsky a tzv. odborné komisie, resp. odborné pracovné komisie, ktoré podl'a dostupných zdrojov predstavovali uholný kameň činnosti OPS. ${ }^{22}$ Do odborných komisií boli zarad'ovaní vynikajúci učitelia-jednotlivci, ktorí mali vo svojich okresoch pracovat' na úlohách zodpovedajúcich ich odbornej špecializácii. Odborné komisie boli totiž diferencované podl'a jednotlivých učebných predmetov, ktorým sa mali vo svojej činnosti venovat'. ${ }^{23}$ Okrem toho boli vo vertikálnom smere v závislosti od konkrétneho stupňa okresných škôl špecializované na odborné komisie pre školy I., II. a III. stupňa. ${ }^{24}$

Pedagogické zbory boli taktiež diferencované na tzv. pedagogické okrsky. ${ }^{25}$ Ich členovia sa najskôr schádzali v dvojmesačných intervaloch, od mája 1950 sa stretávanie okrskov zintenzívnilo na každý druhý týždeň. ${ }^{26}$ Zatial' čo okrsky spočiatku fungovali, rovnako ako odborné komisie, podl'a stupňa škôl, na konci školského roka 1949/1950 došlo k reorganizácii okrskov na tzv. úseky. Tie na rozdiel od pôvodných okrskov, $\mathrm{v}$ súlade $\mathrm{s}$ teritoriálnym princípom, $\mathrm{v}$ rámci jedného úseku „sústred'ovali školy všetkých stupňov okolo školy strednej /školy materské, národné a stredné/.27

\footnotetext{
${ }_{22}^{2}$ „Podl'a počtu aktívnych spolupracovníkov vytýčili si OPS pracovné úlohy pre svoje odborné komisie, v ktorých je t’ažisko práce OPS. “ Z činnosti OPS na Slovensku, s. 21. „Ťažisko práce v OPS bolo sústredené do odborných pracovných komisií." SNA, fond Povereníctvo školstva, Kolégium povereníctva. 1950. Gremiálne porady, i. č. 435 - 447. Kr. č. 177. Okresné a krajské pedagogické sbory. Referát priložený k materiálu týkajúcemu sa XV. gremiálnej porady PŠVU zo dňa 8. decembra 1950, s. 1.

${ }^{23}$ PAVLOV, I.: Náčrt histórie idey d’alšieho vzdelávania, s. 60.

${ }^{24}$ Napríklad v Rimavskej Sobote boli po založení OPS ustanovené jednotlivé odborné komisie podl'a stupňov škôl v okrese: pre detské opatrovne, l'udové a meštianske školy a pre gymnáziá. Pozri viac: Z činnosti OPS na Slovensku. In: Zvesti Štátneho pedagogického ústavu v Bratislave. Príloha časopisu Jednotná škola. Bratislava : Štátne pedagogické nakladatel'stvo, II. polrok 1948, s. 17.; ŠPÚ odborným komisiám stanovil úlohy týkajúce sa výskumu nových učebných osnov, učebníc a učebných pomôcok jednotlivých vyučovacích predmetov na školách I,. II. a III. stupňa.; EDEDY, Ján: Odborné pracovné komisie pedagogických sborov. In: Zvesti Štátneho pedagogického ústavu v Bratislave. Príloha časopisu Jednotná škola. Bratislava : Štátne pedagogické nakladatel'stvo, I. štvrt'rok 1950, s. 1.

${ }^{25}$ SNA, fond Povereníctvo školstva, Kolégium povereníctva. 1950. Gremiálne porady, i. č. 435 - 447. Kr. č. 177. Okresné a krajské pedagogické sbory. Referát priložený k materiálu týkajúcemu sa XV. gremiálnej porady PŠVU zo dňa 8. decembra 1950, s. 1.

${ }^{26}$ SNA, Okresné a krajské pedagogické sbory. Referát priložený k materiálu týkajúcemu sa XV. gremiálnej porady PŠVU zo dňa 8. decembra 1950, s. 1.

27 SNA, Okresné a krajské pedagogické sbory. Referát priložený k materiálu týkajúcemu sa XV. gremiálnej porady PŠVU zo dňa 8. decembra 1950, s. 1.
} 
Na základe správy o stave okresných a krajských pedagogických zborov pre 15. gremiálnu poradu Povereníctvo školstva, vied a umení zo dňa 8. decembra 1950 môžem konštatovat', že v rámci okrskov/úsekov prebiehalo vzdelávanie učitel'ov, zatial' čo odborné komisie združovali len „4 - 8 najlepších teoretikov a praktikov v okrese, zameraných na určitú problematiku “. ${ }^{28}$ Okrsky/úseky teda predstavovali vzdelávací a odborné komisie vedecko-výskumný organizačný komponent pedagogických zborov. Fungovanie OPS malo na starosti predsedníctvo na čele s predsedom a výbor OPS, ${ }^{29}$ príslušníci členských základní pedagogických zborov sa zhromažd'ovali na plenárnych schôdzach. ${ }^{30} \mathrm{Z}$ úsekových schôdzíporád a odborných učitel'ských konferencií boli vyhotovované stručné zápisnice informujúce o ich programe, riešených problémoch a otázkach nasmerovaných na ŠPÚ. ${ }^{31}$ Súhrnnú správu o činnosti OPS do ústredia zasielali v štvrt'ročných intervaloch, v prípade významných akcií bolo potrebné ŠPÚ informovat' správou ihned’.32, KPS na ŠPÚ oznamovali „,každú úpravu, ktorú posielajú okresným pedagogickým sborom", zasielali odpisy zápisníc zo všetkých výborových schôdzí a na ŠPÚ z KPS taktiež putovali „polročné správy o vlastnej činnosti a skúsenostiach“.33

K novembru 1950, ked' prebehla reorganizácia pedagogických zborov - ide o medzník, ktorým moje úvahy ohl'adom pedagogických zborov končia - bolo založených 81 OPS. ${ }^{34}$ Sedemdesiatdevät' percent z tohto počtu, čiže 64 OPS, vzniklo do konca roka $1948 .{ }^{35}$ Zatial' čo prvý OPS na

\footnotetext{
${ }^{28}$ SNA, Okresné a krajské pedagogické sbory. Referát priložený k materiálu týkajúcemu sa XV. gremiálnej porady PŠVU zo dňa 8. decembra 1950, s. 1.

${ }^{29}$ Výbor OPS pozostával z členov predsedníctva OPS, zástupcov škôl I., II. a III. stupňa a škôl, ktoré boli v obvode školského inšpektorátu, predsedov odborných komisií (resp. odborných referentov), predsedov okrskov a okresných školských inšpektorov a riaditel'ov škôl III. stupňa (pokial' neboli do predsedníctva alebo do výboru OPS zvolení). Návrh na organizačný poriadok okresných pedagogických sborov (OPS) na Slovensku. Paragraf č. 12. In: Zvesti Štátneho pedagogického ústavu v Bratislave. Príloha časopisu Jednotná škola. Bratislava : Štátne pedagogické nakladatel'stvo, II. štvrt'rok1949, s. 23.

30 Matej Beňo ako komponenty organizačnej štruktúry OPS uviedol plenárne schôdze, predsedníctvo, výbor, plenárne schôdze okrsku a odborné komisie. BEŇO, Matej: Z histórie okresných pedagogických stredísk na Slovensku, s. 358.

${ }^{31}$ EDEDY, Ján: Pracovný styk Štátneho pedagogického ústavu s KPS a OPS. In: Zvesti Štátneho pedagogického ústavu $v$ Bratislave. Príloha časopisu Jednotná škola. Bratislava : Štátne pedagogické nakladatel'stvo, II. štvrt'rok 1950, s. 21 - 22.

${ }^{32}$ Návrh na organizačný poriadok okresných pedagogických sborov (OPS) na Slovensku. Diel II. Úlohy a prostriedky. Paragraf 5. In: Zvesti Śtátneho pedagogického ústavu v Bratislave. Príloha časopisu Jednotná škola. Bratislava : Štátne pedagogické nakladatel'stvo, II. štvrt'rok1949, s. 21.

33 EDEDY, J.: Pracovný styk Štátneho pedagogického ústavu s KPS a OPS, s. 24.

${ }^{34}$ SNA, Okresné a krajské pedagogické sbory. Referát priložený k materiálu týkajúcemu sa XV. gremiálnej porady PŠVU zo dňa 8. decembra 1950, s. 1.

${ }^{35}$ SNA, Okresné a krajské pedagogické sbory. Referát priložený k materiálu týkajúcemu sa XV. gremiálnej porady PŠVU zo dňa 8. decembra 1950, s. 1.
} 
Slovensku bol založený dňa 13. októbra 1947 v Prešove ${ }^{36}$, v prvom polroku 1948 už boli OPS založené v sídle 33 okresných inšpektorátov (v šiestich prípadoch existovali len prípravné výbory). ${ }^{37} \mathrm{Na}$ margo konca roka 1949 môžeme hovorit' už o počte 75 OPS. ${ }^{38}$

Je vhodné podotknút', že začlenenie pedagogických pracovníkov do pedagogických zborov bolo oficiálne deklarované v rovine dobrovol'nosti. ${ }^{39}$ Pohl'ad na návrh organizačného poriadku OPS na Slovensku, uverejnený na stránkach Zvestí ŠPÚ z druhého štvrt'roka 1949, nám však ukazuje, že ŠPÚ výborom OPS na schválenie navrhol zásadnú zmenu v 2. bode druhého paragrafu - členmi OPS sa mali stat' všetci tí profesori a učitelia $\mathrm{z}$ toho-ktorého okresu, ktorí boli členmi Zväzu zamestnancov školstva a osvety. Zmyslom takejto zmeny malo byt' zväčšenie členskej základne OPS, čo malo teoreticky rozložit’ plnenie úloh, vytýčených zo strany ŠPÚ, na viac osôb. ${ }^{40}$ Organizátori pedagogických zborov však mohli každopádne počítat's rozhodne nezanedbatel'nou mierou nadšenia mnohých pedagógov

${ }^{36}$ Klúčový zástoj na založení prvého okresného pedagogického zboru mal pracovník ŠPÚ František Karšai. Pozri viac: RIČALKA, Michal: Doc. PhDr. František Karšai, CSc., zakladatel' Okresného pedagogického zboru v Prešove. In: PAVLOV, I. (ed.): 50 rokov venovaných d'alšiemu vzdelávaniu, s. 78.

37 V prvom polroku 1948 boli OPS založené v nasledovných školských inšpektorátov: 1. Bánovce nad Bebravou, 2. Banská Štiavnica, 3. Bardejov, 4. Bratislava I. (mala len prípravný výbor), 5. Bratislava II. (mala len prípravný výbor), 6. Bratislava III., 7. Brezno nad Hronom, 8. Čadca, 9. Kežmarok, 10. Komárno, 11. Košice II., 12. Král'ovský Chlmec (mal len prípravný výbor), 13. Kremnica, 14. Krupina, 15. Levice, 16. Liptovský Svätý Mikuláš (mal len prípravný výbor), 17. Lučenec, 18. Modrý Kameň, 19. Nitra, 20. Nové Mesto nad Váhom, 21. Nové Zámky I., 22. Nové Zámky II. (mal len prípravný výbor), 23. Revúca (mal len prípravný výbor), 24. Rimavská Sobota, 25. Rožňava, 26. Ružomberok, 27. Spišská Nová Ves, 28. Trnava, 29. Turčiansky Svätý Martin, 30. Vel'ká Bytča, 31. Žilina, 32. Medzilaborce, 33. Stropkov. Z činnosti OPS na Slovensku. In: Zvesti Štátneho pedagogického ústavu v Bratislave. Príloha časopisu Jednotná škola. Bratislava : Štátne pedagogické nakladatel'stvo, I. polrok 1948, s. 21.

${ }^{38}$ SNA, Okresné a krajské pedagogické sbory. Referát priložený k materiálu týkajúcemu sa XV. gremiálnej porady PŠVU zo dňa 8. decembra 1950, s. 1.

39 „Členstvo v OPS je dobrovol'né a bezplatné a právny poriadok je predpísanýv Organizačnom poriadku. "EDEDY, Ján: O spolupráci Štátneho pedagogického ústavu a okresných pedagogických sborov. In: Zvesti Štátneho pedagogického ústavu v Bratislave. Príloha časopisu Jednotná škola. Bratislava : Štátne pedagogické nakladatel'stvo, I. štvrt'rok 1949, s. 8.

40 „Štátny pedagogický ústav v Bratislave predkladá svojim okresným pedagogickým sborom prepracovaný návrh na organizačný poriadok sborov, aby výbory okresných pedagogických sborov tento návrh preštudovali a svoje posudky nám najneskôr do konca júna 1949 poslali na Ústav. [...] Dôležitá je zmena u § 2 bod 2, v smysle ktorej členmi okresných pedagogických sborov stávajú sa všetci učitelia-profesori v okrese, ktorí sú členmi SZčO (ido o Zväz zamestnancov školstva a osvety - pozn. M. G.). Týmto sa značne zväčší počet členstva v sboroch, práca na úlohách okresných pedagogických sborov prenesie sa na viacerých a vytvorísa možnost' lepšie organizovat' odborné pracovné komisie. "Návrh na organizačný poriadok okresných pedagogických sborov (OPS) na Slovensku. Paragraf 2; článok 2. In: Zvesti Štátneho pedagogického ústavu v Bratislave. Príloha časopisu Jednotná škola. Bratislava : Štátne pedagogické nakladatel'stvo, II. štvrt'rok 1949, s. 20. 
pre myšlienku participácie na rozvoji výskumu školstva nielen v celoštátnom, ale aj v regionálnom kontexte. Matej Beňo aj Ivan Pavlov sa na základe dobových prameňov zhodujú v konštatovaní, že OPS do určitej miery vznikli spontánne na základe autentickej iniciatívy učitel'ov. ${ }^{41}$ Podl'a Ivana Pavlova vznik OPS „bol výsledkom aktívnej a obetavej práce mnohých nadšencov myšlienky učitel'skej svojpomoci. Je potrebné zdôraznit', že nešlo len o administratívne, centralisticko-direktívne rozhodnutie, o čom svedčí postupné utváranie OPZ v jednotlivých okresoch $v$ priebehu dvoch rokov. Vo všetkých okresoch prípravné výbory zvolávali plenárne zasadnutia učitel'ov, školských pracovníkov a konštituovala sa siet' OPZ. V niektorých okresoch sa vytvorenie dobrovol'ného pedagogického zboru uskutočnilo už skôr a vzišlo z iniciatívy samých učitel'ov a školských pracovníkov." ${ }^{42}$ Ako praktický príklad Ivan Pavlov uvádza vznik prvého slovenského OPS: „V Prešove bol prípravný výbor na založenie OPZ vytvorený 8. 7. 1947 za aktívnej účasti Františka Karšaia. Dňa 13. 10. 1947 sa uskutočnila plenárna schôdza 300 učitel'ov, ktoré založili prvý OPZ na Slovensku. "43 Zakladatel' prešovského OPS doc. PhDr. František Karšai, budúci popredný komeniológ, ako pracovník ŠPÚ „V teréne“ v priebehu rokov 1947 - 1949 založil OPS aj vo Svidníku a v Giraltovciach. ${ }^{4}$ Podl'a referátu o okresných a krajských pedagogických zboroch: „Štátny pedagogický ústav začal zakladat' pedagogické sbory koncom roka 1947. Zakladanie sa po okresoch vykonávalo z vlastnej iniciatívy učitel'ov. “45 Pokial' vezmeme do úvahy uvedené fakty, je podl'a mňa možné dôjst' k nasledovnému záveru: myšlienku pedagogických zborov pracovníci ŠPÚ do reality previedli prostredníctvom inšpektorov (OPS boli zriad'ované v sídlach školských inšpektorátov ${ }^{46}$ ), ktorí zorganizovali prihlásených učitel'ov a školských pracovníkov do OPS. Prípravné výbory a následne sformované OPS sa však rozhodne aspoň v začiatočnej fáze existencie pedagogických zborov tešili určitému nadšeniu časti slovenských pedagógov. ŠPÚ pre nich vytvoril inštitucionálnu základňu umožňujúcu, prinajmenšom na papieri, ciel'avedomé vzdelávanie - zlepšovanie kvalifikácie pedagógov a ich zapojenie do projektu plánovitého rozvoja slovenského školstva vrátane účasti na vedeckom výskume problematiky vyučovacieho procesu.

\footnotetext{
${ }^{41}$ BEŇO, Matej: Z histórie okresných pedagogických stredísk na Slovensku, s. 358.; PAVLOV, I.: Náčrt histórie idey d'alšieho vzdelávania, s. 60.

42 PAVLOV, I.: Náčrt histórie idey d'alšieho vzdelávania, s. 60.

${ }^{43}$ PAVLOV, I.: Náčrt histórie idey d’alšieho vzdelávania, s. 60.

${ }^{44}$ RIČALKA, M.: Doc. PhDr. František Karšai, CSc., s. 78.

${ }^{45}$ SNA, Okresné a krajské pedagogické sbory. Referát priložený k materiálu týkajúcemu sa XV. gremiálnej porady PŠVU zo dňa 8. decembra 1950, s. 1.

46 Zprávy: Predškolská výchova v okresných pedagogických sboroch. In: Jednotná škola, roč. III., č. 5, 1947 - 1948, s. 227.
} 
Asistencia pedagogickým zborom pri ich výskumných aktivitách však zo strany učitel'ov zásade dobrovol'nosti nepodliehala, o čom nás informuje obežník č. j. 912/49 od referenta ŠPÚ dr. Štefana Palúcha (v zastúpení riaditel'a Gustáva Pavloviča), ktorý bol uverejnený v Zvestiach ŠPÚ z druhého štvrt'roka 1949. Školskí inšpektori a členovia predsedníctiev OPS boli na základe ustanovení výnosu Povereníctva školstva, vied a umení č. 5482-prez. zo dňa 12. augusta 1948, výnosu č. 5506-prez. zo dňa 16. augusta 1948 a výnosu č. 5346-prez. zo dňa 31. augusta 1948 upozornení, že zbieranie skúseností s novozavedenými učebnými programami, plánmi a osnovami pre materské, národné a stredné školy predstavovalo povinnost' pre všetkých učitel'ov pôsobiacich na uvedených stupňoch školskej sústavy. ${ }^{47}$ Inšpektorov tak ŠPÚ činil pred PŠVU zodpovednými za dodanie elaborátov, obsahujúcich učitel'mi spísané poznatky a skúsenosti, predsedníctvam pedagogických zborov - OPS mali zozbieraný a svojimi odbornými pracovnými komisiami roztriedený výskumný materiál zaslat' na d’alšie spracovanie na ŠPÚ do Bratislavy. ${ }^{48}$ Skúsenosti pedagógov s novými učebnými osnovami boli analyzované na mesačných konferenciách učitel'ských zborov, čo mali školskí inšpektori dôsledne kontrolovat': „Výskum nových učebných plánov a programov je kolektívna pedagogická práca, na ktorej má byt' zúčastnený každý náš učitel'. Od svedomitosti a úsilia nášho učitel'stva na tejto práci bude závisiet' kvalitatívna a kvantitatívna stránka definitívnej úpravy pracovného programu, učebných plánov a osnov. Preto školských inšpektorov a predsedníctvo okresných pedagogických sborov činíme zodpovednými pred Povereníctvom školstva, vied a umení za prevádzanie žiadaného výskumu po našich školách!"49 Povinnost'ou každého pedagogického pracovníka bolo v tejto súvislosti participovat' na prípravnom aj následnom výskume novokoncipovaných a novozavedených učebných plánov. ${ }^{50}$

\footnotetext{
${ }^{47}$ Skúsenosti s novým učebným programom, učebnými plánmi a osnovami pre I. a II. školský stupeň mali učitelia zaznamenávat' a spracovávat' na základe pokynov uverejnených vo Zvestiach ŠPÚ na I. štvrt'rok 1949 (str. č. 9). Obežník ŠPÚ č. j. 912/49. Prieskum nových učebných osnov. In: Zvesti Štátneho pedagogického ústavu v Bratislave. Príloha časopisu Jednotná škola. Bratislava : Štátne pedagogické nakladatel'stvo, II. štvrt'rok 1949, s. 25.

48 Obežník ŠPÚ č. j. 912/49. Prieskum nových učebných osnov. In: Zvesti Štátneho pedagogického ústavu v Bratislave. Príloha časopisu Jednotná škola. Bratislava : Štátne pedagogické nakladatel'stvo, II. štvrt'rok 1949, s. 25.

49 Obežník ŠPÚ č. j. 912/49, s. 25.

50 ŠPÚ sa hned' v „rannom“ období svojej existencie zameral na prepracovanie náplne škôl všetkých stupňov, čo v praxi znamenalo najmä transformáciu učebných programov, plánov a osnov. Podl'a riaditel'a ŠPÚ G. Pavloviča: „,V tomto zmysle sme sa usilovali vypracovat' spoločne s najširším okruhom dostupných odborníkov z jednotlivých predmetov zo škôl i školských úradov, ako aj za najužšej spolupráce s pražským Výskumným ústavom pedagogickým pracovný program pre materské školy, učebné plány a osnovy pre gymnáziá, ktoré sa rozosielajú na školy, aby sa podl'a nich začalo vyučovat' vo všetkých triedach už tohto roku."
} 
Okresné a krajské pedagogické zbory ...

Vzt’ah medzi centrom - ŠPÚ v Bratislave a siet'ou okresných a od rokov 1949/1950 aj krajských pedagogických zborov stál na princípe vzájomnej spolupráce, v rámci ktorej ŠPÚ prirodzene plnil funkciu záväzného usmerňovatel'a. ŠPÚ mal predstavovat' „stredisko, do ktorého sa budú zbiehat' tie vzácne skúsenosti a zdarilé originálne myšlienky, ktoré v poctivej a často namáhavej školskej práci našich učitel’ov a profesorov vzkrsnú, aby potom ŠPÚ spoločne prepracované obohatili našu pedagogickú vedu“.51 Podl'a návrhu organizačného poriadku OPS realizovali úlohy vytýčené ŠPÚ a súčasne mali právo smerom $\mathrm{k}$ ŠPÚ predkladat' iniciatívne návrhy na odborné posúdenie a spracovanie školských otázok. ${ }^{52}$ Krajské pedagogické zbory, existujúce v sídlach krajských národných výborov (Bratislava, Nitra, Banská Bystrica, Prešov, Košice, Žilina), fungovali ako koordinačné jednotky, ktoré usmerňovali OPS vo výskumnej aj organizačnej rovine, kontrolovali ich hospodárenie, a zároveň mali smerom k ŠPÚ „podávat iniciatívne návrhy za celý kraj Štátnemu pedagogickému ústavu“.53 OPS aj KPS pred ŠPÚ zastupoval predseda, ktorý centru taktiež predkladal správu o činnosti svojho pedagogického zboru. ${ }^{54} \mathrm{~V}$ záujme zvýšenia kvality vzájomnej spolupráce troch predmetných organizačných telies ŠPÚ, KPS a OPS - bola pri ŠPÚ zriadená komisia (poradný zbor) pre pedagogické zbory, ktorá mala za úlohu spoločne s ŠPÚ „prejednávat' a pripravovat' pracovnú problematiku pedagogických sborov".55

Čo sa týka ekonomického fungovania pedagogických zborov, ich finančné náklady na prevádzku a vedeckú činnost’ boli zo strany ŠPú dotované režijným preddavkom z úveru od Povereníctva školstva, vedy

PAVLOVIČ, Gustáv: Štátny pedagogický ústav a úsilie o novú školu. In: PAVLOVIČ, Gustáv (ed.): K histórii československej socialistickej školy. Bratislava : Slovenské pedagogické nakladatel'stvo, 1977, s. 66.

${ }^{51}$ EDEDY, Ján: O spolupráci Štátneho pedagogického ústavu a okresných pedagogických zborov. In: Zvesti Štátneho pedagogického ústavu v Bratislave. Príloha časopisu Jednotná škola. Bratislava : Štátne pedagogické nakladatel'stvo, I. štvrt'rok 1949, s. 6.

52 „OPS podl'a paragrafu 27 štatútu Ústavu majú úlohu v dohode so Štátnym pedagogickým ústavom (ŠPÚ) a školskými úradmi: [...] „h) pracovat'na úlohách, ktoré im ŠPÚ zverí; ch) predkladat' ŠPÚ iniciatívne návrhy na odborné posúdenie alebo spracovanie." Návrh na organizačný poriadok okresných pedagogických sborov (OPS) na Slovensku. Diel II. Úlohy a prostriedky. Paragraf 4. In: Zvesti Štátneho pedagogického ústavu v Bratislave. Príloha časopisu Jednotná škola. Bratislava : Štátne pedagogické nakladatel'stvo, II. štvrt'rok 1949, s. 21.

53 Zakladáme krajské pedagogické sbory. In: Zvesti Štátneho pedagogického ústavu v Bratislave. Príloha časopisu Jednotná škola. Bratislava : Štátne pedagogické nakladatel'stvo, III. IV. štvrt'rok 1949, s. 33.

${ }^{54}$ Návrh na organizačný poriadok okresných pedagogických sborov (OPS) na Slovensku. Paragraf 11, str. 22.; Návrh na organizačný poriadok krajských pedagogických sborov. Paragraf 11, s. 37.

55 Založili sme krajské pedagogické sbory. In: Zvesti Štátneho pedagogického ústavu v Bratislave. Príloha časopisu Jednotná škola. Bratislava : Štátne pedagogické nakladatel'stvo, I. štvrt'rok 1950, s. 12. 
a umenia. ${ }^{56}$ Podmienku čerpania dotácie predstavovalo zaslanie vyčíslených požiadaviek - rozpočtu k 1 . júlu daného roka. ${ }^{57} \mathrm{Na}$ poli hospodárenia s pridelenými finančnými prostriedkami došlo k určitým problémom, ked'že niektoré OPS nedbali na riadnu účtovnú evidenciu a dodržiavanie stanovených pravidiel. ${ }^{58}$ Zásadným problémom, ktorému OPS museli po svojom založení čelit', bola nedostatočná výška poskytnutej dotácie. Pedagogickým zborom bolo preto odporúčané hl'adat' možnosti doplnkového financovania od orgánov štátnej správy (MNV, ONV), resp. využit' šancu získat' prípadný príjem z organizovania odborných akcií. ${ }^{59}$

\section{Stanovovanie úloh pre pedagogické zbory v kontexte vzájom- nej komunikácie ŠPÚ a pedagogických zborov}

Činnost' členov pedagogických zborov bola na rok dopredu precízne plánovaná60, čo bolo $\mathrm{v}$ praktickej rovine možné aj vd'aka intenzívnej komunikácii OPS a KPS s ŠPÚ. Ako som sa už v predchádzajúcom texte o tom zmienil, v prvých rokoch fungovania pedagogických zborov ŠPÚ s učitel'skou verejnost'ou združenou v OPS a KPS oficiálne komunikoval prostredníctvom Zvestí Štátneho pedagogického ústavu v Bratislave - prílohy odborného pedagogického periodika Jednotná škola. Zbory museli centrum oboznamovat' so všetkými vykonávanými činnost’ami, súčasne ale Zvesti ŠPÚ v článku Štátny pedagogický ústav a okresné pedagogické sbory

\footnotetext{
${ }^{56}$ Návod na hospodárenie krajských a okresných pedagogických zborov. In: Zvesti Štátneho pedagogického ústavu v Bratislave. Príloha časopisu Jednotná škola. Bratislava : Štátne pedagogické nakladatel'stvo, II. štvrt'rok 1950, s. 27.

57 Obežník ŠPÚ. Č. j. 2876/49. Koncoročná správa. Vyčíslenie materiálnych potrieb. Všetkým okresným pedagogickým sborom a školským inšpektorátom na Slovensku. In: Zvesti Štátneho pedagogického ústavu v Bratislave. Príloha časopisu Jednotná škola. Bratislava : Štátne pedagogické nakladatel'stvo, III. - IV. štvrt'rok 1949, s. 45.

58 „Z výročných vyúčtovaní sme zistili, že niektoré okresné pedagogické sbory nesprávne hradia členom OPS cestovné výlohy z finančných prostriedkov, poskytovaných Štátnym pedagogickým ústavom v Bratislave na režijné ciele OPS. Vydávame preto $k$ tejto veci podrobné pokyny a žiadame, aby sa ich okresné pedagogické sbory pridržiavali, lebo príslušní funkcionári sú hmotne zodpovední za správne použitie štátom dotovaných peňazí. "Obežníky ŠPÚ: č. j. 1814/49. Pokyny o hradení cestovných výloh členov OPS. In: Zvesti Štátneho pedagogického ústavu v Bratislave. Príloha časopisu Jednotná škola. Bratislava : Štátne pedagogické nakladatel'stvo, III. - IV. štvrt'rok 1949, s. 44.

${ }^{59}$ Obežníky ŠPÚ. Č. j. 912/49. Dotácia okresných pedagogických zborov. In: Zvesti Štátneho pedagogického ústavu v Bratislave. Príloha časopisu Jednotná škola. Bratislava : Štátne pedagogické nakladatel'stvo, II. štvrt'rok1949, s. 24 - 25.

${ }^{60}$ Príkladom je príprava učitel'ských stretnutí: „Podl'a smerníc Štátneho pedagogického ústavu práca na spomenutých konferenciách je po okresných pedagogických sboroch dopredu precizovaná. Učitel'stvo je okresným pedagogickým zborom na celý rok dopredu informované kto, o čom, kedy, kde a na akej pedagogickej konferencii bude prednášat' a na akej pedagogickej práci bude pracovat'." Plánovanie po okresných pedagogických sboroch. In: Zvesti Štátneho pedagogického ústavu v Bratislave. Príloha časopisu Jednotná škola. Bratislava : Štátne pedagogické nakladatel'stvo, I. štvrt'rok 1949, s. 13.
} 
deklarovali samostatnost' a iniciatívu jednotlivých pedagogických zborov. ${ }^{61}$ Tento článok považujem ohl'adom vymedzenia vzt'ahov ŠPú a pedagogických zborov za zásadný, lebo vel'mi presne špecifikuje právomoci OPS a plánovaco-riadiacu pozíciu ŠPÚ v rámci realizácie vedecko-výskumnej činnosti: „Spolupráca OPS so Štátnym pedagogickým ústavom je vzájomná. Výskumy, ktoré OPS budú vykonávat'v dohode so Štátnym pedagogickým ústavom, vopred sa dôkladne pripravia. Špecifikovat' činnost'OPS tu nemožno, lebo vývoj donáša vždy novšie a novšie problémy. Aby nevznikli nedorozumenia, treba pripomenút', že OPS budú mat' dost' samostatnosti, aby mohli riešit' z vlastnej iniciatívy otázky rázu pedagogického i didaktického. Štátny pedagogický ústav akiste uvíta iniciatívu OPS, ako i ich účast' na plánovaní a organizovaní pedagogickej práce. Môžu uplatňovat' svoje názory, myšlienky plne a nik im v tom nebude prekážat'. Pravda, že OPS budú riešit' všetky problémy miestneho významu v dohode so Štátnym pedagogickým ústavom $v$ Bratislave, lebo ústav musí mat' prehl'ad o všetkých vykonávaných prácach a bude mat'svojich odborníkov pre jednotlivé problémy. Všetku túto prácu ústav usmerní a porovná, aby tá istá vec nerobila sa zbytočne viackrát. Práve v Štátnom pedagogickom ústave musí nájst' učitel'stvo oporu so stránky pedagogickej." ${ }^{\text {"62 }}$ Okrem úloh stanovených za strany ŠPÚ teda mohli členovia OPS sami iniciovat' výskum konkrétnych otázok, vyplývajúcich zo školskej praxe. Referent ŠPÚ Ján Ededy vo svojom príspevku O spolupráci Štátneho pedagogického ústavu a okresných pedagogických sborov, publikovanom v Zvestiach ŠPÚ z I. štvrt'roka 1949, načrtol základný postup spolupráce ŠPÚ a OPS v prípade iniciatívy zdola - z pedagogických zborov. Pokial' iniciatíva k výskumu vzišla z OPS, ŠPÚ mal výskum metodicky pripravit'. Úlohou OPS mala byt' následná realizácia výskumu. Materiál, ktorý vo výskumnom procese vznikol, pracovníci ŠPÚ zhodnotili a spracovali do podoby ucelenej teórie. ${ }^{63}$ Členovia OPS mohli svoje výskumné aktivity nasmerovat' na problémy, vyskytujúce sa v oblasti ich pôsobenia resp. na výskumné otázky, rozvíjanie ktorých považovali za potrebné. Napríklad pedagógovia združení v prešovskom OPS (prvom založenom OPS na Slovensku), fungujúcom pod vedením významného pedagóga Františka Karšaia, si za pracovnú náplň svojej činnosti vytýčili aplikáciu experimentálnych metód, použitel'ných pri testovaní schopností žiakov (psychotechnický výskum inteligencie, didaktické testy). ${ }^{64}$

\footnotetext{
61 Zprávy: Štátny pedagogický ústav a okresné pedagogické zbory. In: Jednotná škola, roč. 3, 1947 - 1948, č. 1, s. 81.

62 Zprávy: Štátny pedagogický ústav a okresné pedagogické zbory, s. 81.

${ }^{63}$ EDEDY, J.: 0 spolupráci Štátneho pedagogického ústavu a okresných pedagogických zborov, s. 7.

${ }^{64}$ Zprávy. Prvý okresný pedagogický sbor na Slovensku. In: Jednotná škola, roč. III., č. 1, 1947 - 1948, s. 31 - 32.
} 
Prvý krok v procese konkrétnej, reálnej spolupráce ŠPÚ s pedagógmi na vedecko-výskumných úlohách predstavovali verejne publikované výzvy na zapojenie učitel'stva do činnosti ústavu. $V$ tomto smere si môžeme všimnút' Zvesti ŠPÚ z I. polroka 1948, ktoré čitatel’ov oboznamovali s výzvou na získanie externých spolupracovníkov, ochotných podiel'at' sa na riešení širokého spektra výskumných problémov. Členovia OPS mali na ŠPÚ oznámit’ mená a miesta pôsobenia potencionálnych ochotných spolupracovníkov, ktorí boli z odborného hl'adiska schopní zapojit' sa do práce na niektorom zo série uvedených šestnástich tematických okruhov. Malo íst' o odborníkov na nasledovné problémy, týkajúce sa pedagogickej teórie a praxe: predškolská výchova, didaktika výučby elementárneho čítania a písania, didaktika predmetov vyučovaných na národných a stredných školách (čítanie, pravopis, sloh, ruský jazyk, vlastiveda, dejepis, zemepis), didaktické problémy málotriednych škôl, vzorové školy, výchova hendikepovanej mládeže, učebnice (tvorba a recenzovanie), pomocné knihy, detská literatúra, bábkové divadlo a divadlo pre mládež, učebné pomôcky (tvorcovia tzv. vzorových kabinetov), otázky školského filmu, umelecká tvorba žiakov a študujúcej mládeže, sociálne problémy, stavby školských budov a zvel'ad'ovanie resp. skrášlovanie ich okolia, tvorba metodík, pedagogická literatúra a školské dokumenty. ${ }^{65}$ Výzva taktiež apelovala na zbieranie historických aj súčasných kníh pedagogickej proveniencie (najmä z oblasti Slovenska), kroník škôl, zápisníc a výročných správ; nakol'ko „na základe tohto materiálu, doteraz neznámeho, bude možné doplnit' obraz vývinu školstva na Slovensku a doplnit' dejiny pedagogiky. "66 Priorita jednotlivých položiek z uvedeného zoznamu výskumných zámerov nebola konštantná. $\mathrm{V}$ priebehu roka 1949 boli zo strany ŠPÚ ako najnaliehavejšie plánované nasledovné úlohy: systematizácia skúseností získaných z pedagogickej praxe, zostavenie učebných osnov pre všetky stupne škôl, príprava mineralogických a petrografických pomôcok zo slovenských geologických nálezísk, budovanie pedagogickej knižnice a čitárne, štúdium didaktických a metodických problémov (predovšetkým vo vyučovaní prírodopisu), schválenie najnutnejších príručiek a pomôcok pre predškolskú výchovu, zriad’ovanie vzorových kabinetov v sídlach OPS a práca na učebniciach pre národné školy, stredné školy a pre gymnáziá. ${ }^{67}$ Sumarizácia uvedených tematických okruhov ma vedie ku konštatovaniu, že Výzvou Okresným

\footnotetext{
${ }^{65}$ Výzva Okresným pedagogickým sborom na získanie externých spolupracovníkov. In: Zvesti Štátneho pedagogického ústavu v Bratislave. Príloha časopisu Jednotná škola. Bratislava : Štátne pedagogické nakladatel'stvo, I. polrok 1948, s. 22 - 23.

${ }^{66}$ Výzva Okresným pedagogickým sborom na získanie externých spolupracovníkov, s. 23.

${ }^{67}$ EDEDY, J.: O spolupráci Štátneho pedagogického ústavu a okresných pedagogických zborov, s. 6- 7 .
} 
pedagogickým sborom na získanie externých spolupracovníkov ŠPÚ deklaroval záujem získat' spolupracovníkov pre každý vyučovací predmet. Pri pohl'ade na súpis vedecko-výskumných úloh, ktoré boli pre ŠPÚ relevantné v oblasti vedeckého výskumu ${ }^{68}$, ešte viac vynikne náročnost' poslania tejto inštitúcie - vedecky skúmat' slovenskú pedagogiku a na základe výskumných výsledkov navrhovat' ciele výchovnej a vzdelávacej činnosti, vrátane účasti na zlepšovaní výchovnej praxe (štúdium a navrhovanie učebných plánov, osnov a podobne). ${ }^{69}$ Rozsah stanovených zámerov a výskumných problémov s dosahom na celé územie Slovenska $^{70}$ a pre každý vyučovací predmet logicky nebol zvládnutel'ný pre niekol'ko desiatok vedeckých pracovníkov ŠPÚ bez podpory rozsiahlej a funkčnej siete ochotných a spolupracujúcich pedagógov, pôsobiacich vo vyučovacej praxi.

\section{Odborné komisie}

Základný komponent, ktorý v štruktúre jednotlivých pedagogických zborov usmerňoval vedecko-výskumnú prácu, predstavovali tzv. odborné komisie. Podl'a Návrhu na organizačný poriadok OPS na Slovensku mali v rámci odborných komisií pracovat' „na otázkach pedagogických a didaktických členovia OPS všetkých stupňov a druhov škôl v okrese ".71 Ako upozorňuje Ivan Pavlov, odborné komisie, zastrešujúce skúsených pedagógov, sa utvárali pre skupiny učebných predmetov, pre jednotlivé učebné predmety, pre tvorbu učebných osnov a pre riešenie „aktuálnej problematiky regiónu, stupňa, druhu školy". ${ }^{72} \mathrm{~V}$ závislosti od portfólia riešených problémov už spomínaná správa o okresných a krajských pedagogických zboroch diferencovala sedem typov odborných komisií: pre jednotlivé vyučovacie predmety, pre učebnice jednotlivých vyučovacích predmetov, pre výskum učebných pomôcok, pre doučovacie skupiny a

\footnotetext{
${ }^{68}$ Výzva Okresným pedagogickým sborom na získanie externých spolupracovníkov, s. 22. ${ }^{69}$ Pozri viac: PIVOVARNÍK, Ján: Zriad’uje sa Štátny pedagogický ústav v Bratislave. In: Jednotná škola, roč. II., s. 220 - 222.; Desat' rokov Výskumného ústavu pedagogického v Bratislave, s. 386 - 387. Porovnaj s: Výnos Povereníctva školstva, vied a umení zo dňa 24. januára 1949, č. 426-prez.leg., ktorým sa vydáva Organizačný poriadok Štátneho pedagogického ústavu v Bratislave. Číslo 42. In: Školské zvesti. Publikačný orgán Povereníctva školstva, vied a umení, roč. V., 28. február 1949, sošit č. 4. Čast' I. Úlohy odbornej činnosti Štátneho pedagogického ústavu v Bratislave, s. $134-135$.

70 „Činnost' ŠPÚ mala zahrnút' celé Okresné pedagogické územie Slovenska a mala zachytit' všetky zbory, pracovníkov na všetkých stupňoch škôl, vedecké inštitúcie, zaoberajúce sa otázkami pedagogiky a jej pomocnými vedami. "PŠENÁK, Jozef: Úloha Štátneho pedagogického ústavu vo zvyšovaní úrovne pedagogického myslenia. In: FERLIKOVÁ, K. (ed.): Pamätnica pri príležitosti 60. výročia, s. 13.

${ }^{71}$ Návrh na organizačný poriadok okresných pedagogických sborov (OPS) na Slovensku. Paragraf 15; článok 1, s. 23.

72 PAVLOV, I.: Náčrt histórie idey d'alšieho vzdelávania učitel’ov na Slovensku, s. 60.
} 
záujmové krúžky, pre spoluprácu školy a rodiny, pre sút’aženie na školách a pre priekopnícke hnutie. ${ }^{73}$ ŠPÚ riadil odborné komisie v niekol'kých fázach: ich založenie, pridel'ovanie úloh a prijímanie výsledkov činnosti odborných komisií vrátane reagovania na iniciatívne návrhy zdola od komisií. V nasledujúcich riadkoch sa pokúsim uvedené aspekty priblížit' podrobnejšie.

Čo sa týka zakladania odborných komisií, ich sformovanie, podobne ako v prípade zakladania pedagogických zborov, priamo súviselo s činnost'ou samotného OPS a súčasne bolo výsledkom záujmu združených pedagógov. Zo správ z činnosti OPS sa totiž dozvedáme o konkrétnych komisiách pre rôzne učebné predmety, ktoré si pedagógovia založili na pôde jednotlivých OPS. ${ }^{74}$ Učebnicové komisie pre všetky stupne škôl a väčšinu vyučovacích predmetov boli v prvej polovici roka 1948 založené na základe prihlášok učitel'ov z celého Slovenska, ktorí boli ochotní mat' účast' na tvorbe nových, prípadne na prepracovávaní už existujúcich učebníc. ${ }^{75}$ Výzva k organizovaniu učebnicových komisií (Zvesti ŠPÚ, 1. polrok 1948) sa opiera o vel'mi zaujímavé zdôvodnenie zostavovania odborných komisií, spočívajúce v prísloví „Kol'ko hláv, tol'ko rozumov“. ŠPÚ totiž deklaroval snahu využívat' kolektívny potenciál skúsených odborníkov, ktorý v prípade odborných komisií prirodzene vstupoval do hry. ${ }^{76}$

Konkrétna výskumná orientácia odborných komisií primárne vychádzala z priorít ŠPÚ: „Komisiám pridel'ujú pracovné problémy jednotlivé referáty Štátneho pedagogického ústavu a komisie organizujú štúdium

\footnotetext{
${ }^{73}$ SNA, fond Povereníctvo školstva, Kolégium povereníctva. 1950. Gremiálne porady, i. č. 435 - 447. Kr. č. 177. Okresné a krajské pedagogické sbory. Referát priložený k materiálu týkajúcemu sa XV. gremiálnej porady PŠVU zo dňa 8. decembra 1950, s. 1.

${ }_{74}$ Pozri viac v jednotlivých vydaniach Zvestí Štátneho pedagogického ústavu v Bratislave.

75 „V obežníku z 21. februára 1948, ktorý sme rozposlali na riaditel'stvá škôl a školské inšpektoráty, apelovali sme na všetkých kolegov, aby sa nám ohlásili a prihlásili $k$ tejto projektovanej práci. Výsledok je radostný. Dnes máme z tejto akcie kartotéku, ktorá obsahuje nielen osobné, ale i záujmové dáta skoro 300 učitel'ov z celého Slovenska. Na základe prihlášok a podl'a menného zoznamu známych nám autorov podarilo sa nám zostavit' učebnicové komisie pre všetky druhy škôl, aj pre takmer všetky predmety. "Komisie pre sostavovanie učebníc. In: Zvesti Štátneho pedagogického ústavu v Bratislave. Príloha časopisu Jednotná škola. Bratislava : Štátne pedagogické nakladatel'stvo, I. polrok 1948, s. 24.

76 „Učebnice sa dosial' najčastejšie robili tak, že sa prepisovali učebnice staré, vystrihovali sa $z$ nich články alebo sa prekladali s povinnou zákonitou obmenou učebnice inojazyčné. Autorov učebníc, sostavených takouto metódou, hnala do roboty najčastejšie zárobková ambícia. Pravda, $v$ časoch blízko poprevratových to bývala i nástojčivost'. V časoch pokojných zoskupovali sa autori v komisie využívajúc pravdivosti príslovia „Kol'ko hláv, tol'ko rozumov". Istotne, že práca spojených rozumov bola lepšia ako práca predošlých. Štátny pedagogických ústav využivajúc týchto skúseností rozhodol sa zostavovat' učebnice v komisiách, ním organizovaných. Vedeli sme, že naši l'udia po školách majú vel'a skúseností; je našou úprimnou túžbou dostat' všetkých do práce." Komisie pre sostavovanie učebníc. In: Zvesti Štátneho pedagogického ústavu v Bratislave. Príloha časopisu Jednotná škola. Bratislava : Štátne pedagogické nakladatel'stvo, I. polrok 1948, s. 24.
} 
problémov v školskej praxi, shromažd'ovanie materiálu a jeho čiastočné spracovávanie (roztriedenie materiálu, opis a jeho analýzu."77 V nami sledovanom rozpätí rokov 1947 - 1950 ŠPÚ komisie usmerňoval v záujme riešenia pre Ústav naliehavých otázok - výskum učebných osnov jednotlivých vyučovacích predmetov na školách I., II. a III. stupňa, výskum nových učebníc na školách I. - III. stupňa, problematika doučovacích skupín, spolupráce školy a rodiny, málotriednych škôl, predškolskej výchovy a zriad'ovania škôl..$^{78}$ Zvesti ŠPÚ prinášali praktické pokyny, podl'a ktorých mali OPS a v rámci nich zriadené odborné komisie realizovat' riešenie vytýčených výskumných úloh. Okrem praktických informácií o formálnom postupe pri ich riešení pokyny obsahovali zoznamy tematických okruhov, ktorým sa OPS mali venovat'. Ján Ededy v článku Sústredenie pedagogickej práce vokresných pedagogických sboroch uviedol a podrobne rozpísal niekol'ko problémov, ktoré mali byt' riešené popri hlavných úlohách stanovených zo strany ŠPÚ. Podl'a Jána Ededyho sa „pedagogickí pracovníci každého OPS“ mali zaoberat' predškolskou výchovou, odstraňovaním formálnych vyučovacích metód, zlepšovaním disciplíny žiakov, učebnými pomôckami, žiackymi organizáciami, spoluprácou školy a rodiny a výučbou detí z reslovakizovaných rodín. ${ }^{79}$ Vo Zvestiach ŠPÚ z prvého štvrt'roka 1949 nachádzame súbor štrnástich otázok - kritérií, určených na posudzovanie učebných osnov. ${ }^{80} \mathrm{~K}$ úlohe zaznamenat', zozbierat', usporiadat' a spracovat' skúsenosti pedagógov v záujmových krúžkoch národných a stredných škôl

\footnotetext{
${ }^{77}$ EDEDY, Ján: Odborné pracovné komisie pedagogických sborov. In: Zvesti Štátneho pedagogického ústavu v Bratislave. Príloha časopisu Jednotná škola. Bratislava : Štátne pedagogické nakladatel'stvo, I. štvrt'rok 1950, s. 1.

${ }^{78}$ EDEDY, J.: Odborné pracovné komisie pedagogických sborov, s. $1-2$.

${ }^{79}$ EDEDY, J.: Sústredenie pedagogickej práce v okresných pedagogických sboroch, s. 3 - 11.

80 „Shromažd'ovanie skúseností o nových učebných plánoch a osnovách na škole národnej a strednej vykonáva sa z týchto hl'adísk: 1. Čím a ako umožňujú učebné osnovy uplatnit' zásadu politickej školy? 2. Čím a ako umožňujú učebné osnovy jednotlivých učebných predmetov vychovávat' $k$ československému vlastenectvu? 3. Čím a ako umožňujú učebné osnovy jednotlivých učebných predmetov vychovávat' mládež v duchu socialistickej morálky? 4. Čím a ako prispievajú učebné osnovy jednotlivých učebných predmetov $k$ odstraňovaniu vyučovacieho a výchovného formalizmu - prípadne čím ho zaviňujú? 5. Výskum učebného plánu národnej školy 6. Výskum učebného plánu strednej školy 7. Či je prevedený v učebných osnovách jednotlivých učebných predmetov správny výber učiva v náležitom rozsahu?8. Či je uvedené správne rozvrhnutie učiva na mesiace? 9. Skúsenosti so žiackou organizáciou, Junákom a SSM. 10. Či je v osnovách vystihnutá úloha učitel'a ako výchovného činitel'a (politické uvedomenie, pomer k žiakom ... )? 11. Ako možno pomáhat' žiakom, ktorí pri vyučovaní zaostali a ako tu využit' pomoc schopnejších žiakov? 12. Záujmové krúžky. 13. Ako hodnotit' žiakovu prácu? 14. Príčiny prepadávania žiactva. "Shromažd’ovanie skúseností o nových učebných plánoch a osnovách na škole národnej a strednej a na školách materských. In: Zvesti Štátneho pedagogického ústavu v Bratislave. Príloha časopisu Jednotná škola. Bratislava : Štátne pedagogické nakladatel'stvo, I. štvrt'rok 1949, s. 9 - 10.
} 
(pre obdobia 1. september 1948 - 31. január 1949 a 1. február 1949 28. jún 1949) Zvesti ŠPÚ uverejnili pätnást' kritérií, podl’a ktorých mali pedagógovia sledovaný fenomén hodnotit'. ${ }^{81}$

Samotná odborná činnost' etablovaných komisií vychádzala z ich zamerania - špecializácie vo vertikálnom smere (podl'a stupňa školy) a v smere horizontálnom (vyučovací predmet). Na základe tohto princípu vznikali v rámci OPS početné odborné komisie. Napríklad v OPS Skalica sa sformovalo až dvadsat' pracovných komisiíiz ${ }^{82}$ v Giraltovciach desat' a podobne. ${ }^{83}$ Okrem práce na (zo strany ŠPÚ) stanovených kl'účových vedecko-výskumných úlohách v prehl'adoch činnosti OPS nachádzame pestrú paletu aktivít, ktoré svedčia o záujme aj nevyhnutnej pedagogickej erudovanosti zapojených pedagogických pracovníkov. Činnost' aspoň niekol'kých vybraných odborných komisií sa v krátkosti pokúsim načrtnút'.

OPS v Ružomberku k začiatku roka 1950 zastrešoval pracovnú komisiu pre riešenie problémov predškolskej výchovy, venujúcu sa problematike výchovného plánu; komisiu pre učebné pomôcky stredných škôl, zastrešujúcu mineralogické zbierky stredných škôl v rámci okresu Ružomberok a komisiu škôl III. stupňa, ktorá spracúvala pripomienky k novým učebným osnovám. ${ }^{84}$

V Turčianskom Svätom Martine určení členovia komisie pre elementárne čítanie mali za úlohu zostavit' návod, podl'a ktorého mali všetci učitelia národných škôl daného okresu porovnávaním učebníc a osnov sledovat' tri kvalitatívne kritériá: kompatibilitu výberu faktov

\footnotetext{
81 Ohl’adom praktického fungovania záujmových krúžkov mal byt’ sledovaný záujem všetkých zúčastnených strán (žiak, učitel', rodič, inšpektor a pod.), miera splnenia pokynov publikovaných v osnovách, využité metodické prostriedky a postupy, mimoriadne problémy a potreby, nadobudnuté skúsenosti a podobne. Pozri viac: Shromažd'ujeme skúsenosti a materiál o záujmových krúžkoch na školách I. a II. stupňa. In: Zvesti Štátneho pedagogického ústavu v Bratislave. Príloha časopisu Jednotná škola. Bratislava : Štátne pedagogické nakladatel'stvo, II. štvrt'rok 1949, s. 18 - 20.

82 Členovia OPS Skalica vytvorili 20 pracovných komisií: predškolská výchova, málotriedne školy, prvouka, vlastiveda, slovenský jazyk, ruský jazyk, dejepis, náuka o hospodárstve, zemepis, prírodopis, chémia, fyzika, matematika, kreslenie, náuka o domácnosti, telesná výchova, občianska výchova, pre problémy stredných a odborných škôl, školské zdravotníctvo, obvodná učitel'ská komisia. Z činnosti OPS na Slovensku. In: Zvesti Štátneho pedagogického ústavu v Bratislave. Príloha časopisu Jednotná škola. Bratislava : Štátne pedagogické nakladatel'stvo, I. polrok 1948, s. 21.

${ }^{83}$ V Giraltovciach vznikla výtvarná, jazyková, matematická (počtová) komisia, vlastivedná, telovýchovná, psychologická, sociálna, zdravotná, hudobná pracovná komisia. Z činnosti OPS na Slovensku. In: Zvesti Štátneho pedagogického ústavu v Bratislave. Príloha časopisu Jednotná škola. Bratislava : Štátne pedagogické nakladatel'stvo, I. polrok 1948, s. 21.

${ }^{84}$ Zo života okresných pedagogických sborov. In: Zvesti Štátneho pedagogického ústavu $v$ Bratislave. Príloha časopisu Jednotná škola. Bratislava : Štátne pedagogické nakladatel'stvo, I. štvrt'rok 1950, s. 15 - 16.
} 
z ideologického hl'adiska (marxizmus), mieru dôkladnosti výberu faktov z hl'adiska systematickosti a správnost' spôsobu usporiadania ich výberu z metodického hl'adiska. Učitelia mali takto zozbierané fakty raz mesačne posúvat' príslušnej komisii, ktorá získané skúsenosti spracovala a zosystematizovala. ${ }^{85}$

Členovia pedagogickej odbornej komisie, pôsobiacej v rámci OPS Zvolen, participovali na zostavovaní nového šlabikára, mluvnici a cvičebnici slovenského jazyka, učebnici dejepisu a na osnovách pre predmet matematika pre školy I. stupňa. ${ }^{86}$

Zaujímavou bola mnohotvárna činnost' komisií - pracovných sekcií učiteliek detských opatrovní. Ich pôsobenie spočívalo v nasledovných úlohách: zostavenie výchovného programu - osnov pre detské opatrovne, navrhovanie základného zoznamu výchovných pomôcok (hračiek) resp. námetov výchovných obrazov, vypracovanie vzornej ukážky zamestnávania detí v opatrovni a zostavenie metodicko-didaktickej príručky predškolskej výchovy so zoznamom piesní a hier.87 V Prievidzi profesori miestneho gymnázia zrealizovali výskum vzt'ahu žiakov a školy vo forme ankety. 88

OPS boli výsledky svojich výskumných aktivít povinné zasielat' na KPS a súčasne aj na ŠPÚ. Predovšetkým na poli získavania skúseností $\mathrm{s}$ učebnými programami, plánmi a osnovami sú $\mathrm{k}$ dispozícii presné inštrukcie, ktoré osvetl'ujú spôsob, akým ŠPÚ prijímalo výskumný materiál získaný od pedagógov z vyučovacej praxe. Učitelia materských, národných a stredných škôl mali svoje zistenia koncom príslušného mesiaca podl'a jednotlivých vyučovacích predmetov zaslat' svojmu OPS, kde odborné pracovné komisie získaný materiál zosystematizovali, zhodnotili a zaslali na ŠPÚ. ${ }^{89}$ Napríklad v druhej polovici roka 1948 komisia pre l'udové a meštianske školy v OPS Rimavská Sobota na ŠPÚ predložila 11 pripomienok k učebným plánom a osnovám. ${ }^{90}$ Ked’že ŠPÚ na leto 1949 plánoval práce na zlepšovaní nových učebných osnov pre materské, národné a stredné školy, OPS aj školské inšpektoráty boli na stránkach Zvestí vyzvané, aby od pracovných komisií pre učebné osnovy zozbierali výskumný materiál a do 10. júla 1949 ho odoslali na

\footnotetext{
${ }^{85}$ EDEDY, Ján: Odborné pracovné komisie pedagogických sborov. In: Zvesti Štátneho pedagogického ústavu v Bratislave. Príloha časopisu Jednotná škola. Bratislava : Štátne pedagogické nakladatel'stvo, I. štvrt'rok 1950, s. 6 - 8.

${ }^{86} \mathrm{Z}$ činnosti OPS na Slovensku, s. 18.

87 Zprávy. Predškolská výchova v okresných pedagogických sboroch. In: Jednotná škola, roč, III, č. 5, 1947 - 1948, s. 227.

$88 \mathrm{Z}$ činnosti OPS na Slovensku, s. 21.

${ }^{89}$ Shromažd'ovanie skúseností o nových učebných plánoch a osnovách na škole národnej a strednej a na školách materských, s. 9.

${ }^{90} \mathrm{Z}$ činnosti OPS na Slovensku, s. 17.
} 
ŠPÚ. ${ }^{91}$ Je vhodné poznamenat', že okrem výskumných výstupov ŠPÚ požiadal riaditel'stvá všetkých škôl o poskytnutie školských časopisov, výročných správ, materiálov týkajúcich sa histórie jednotlivých škôl v okresoch, starších učebníc a pedagogickej literatúry vo všeobecnosti. ${ }^{92}$

V stručnosti sa chcem vrátit' k Zvestiam ŠPÚ z prvého štvrt'roka 1949, na stránkach ktorých bol publikovaný text Shromažd'ovanie skúseností o nových učebných plánoch a osnovách na škole národnej a strednej a na školách materských, obsahujúci presný návod na zhodnotenie nových učebných osnov. ${ }^{93} \mathrm{Na}$ ich zostavení sa podiel'al aj ŠPÚ, materiály s poznatkami od učitel'ov spracovali a následne zaslali na ŠPÚ odborné pracovné komisie. ${ }^{94}$ Výsledky výskumu na poli využívania učebných osnov v realite školskej praxe na stránkach Jednotnej školy podrobne analyzoval prednosta I. odboru ŠPÚ Andrej Selecký (venujúci sa výskumu učebných osnov). Na základe spätnej väzby učitel'skej verejnosti vyvodil pät' záverov ${ }^{95}$, vyplývajúcich z realizovaného výskumu, a stanovil perspektívy d'alšej práce na zdokonal'ovaní učebných osnov. ${ }^{96}$

${ }^{91}$ Obežník ŠPÚ. Č. j. 2587/49. Výskumný materiál o osnovách. In: Zvesti Štátneho pedagogického ústavu v Bratislave. Príloha časopisu Jednotná škola. Bratislava : Štátne pedagogické nakladatel'stvo, III. - IV. štvrt'rok 1949, s. 44.

92 Obežník ŠPÚ. Č. j. 1642/49. Obežník o shromaždení výročných zpráv škôl a iných publikácií. Všetkým okresným pedagogickým sborom a školským inšpektorátom na Slovensku. In: Zvesti Štátneho pedagogického ústavu v Bratislave. Príloha časopisu Jednotná škola. Bratislava : Štátne pedagogické nakladatel'stvo, II. štvrt'rok 1949, s. 26 - 27.

${ }^{93}$ Shromažd'ovanie skúseností o nových učebných plánoch a osnovách na škole národnej a strednej a na školách materských, s. 9 - 11.

${ }^{94}$ K vydaniu nových učebných osnov pre jednotlivé stupne škôl v rokoch 1948 - 1949 podrobnejšie pozri prvú kapitolu tejto štúdie. K spracúvaniu výsledkov výskumu nových učebných osnov odbornými komisiami v rámci OPS pozri: Shromažd'ovanie skúseností o nových učebných plánoch a osnovách na škole národnej a strednej a na školách materských. In: Zvesti Štátneho pedagogického ústavu v Bratislave. Príloha časopisu Jednotná škola. Bratislava : Štátne pedagogické nakladatel'stvo, I. štvrt'rok 1949, s. 9.

95 „Ked' sme vcelku zhrnuli odpovede na otázky kladné i záporné, právom môžeme si položit' otázku, aký je výsledok nášho výskumu. [...] S uspokojením možno konštatovat': 1. že naše osnovy vcelku vyhovujú, 2 . že všeobecné zásady výchovy a vyučovania poskytujú istú a pevnú bázu výchovného pôsobenia, 3. že pedagogické zásady, ktoré predchádzajú podrobné utriedenie učiva, poskytujú učitel'stvu isté smernice nielen pri pravidelnej školskej práci, ale i v jeho vzt'ahoch $k$ škole ako ku kultúrnej inštitúcií, k rodičom i k žiackemu kolektívu, 4. výskumom sme sa presvedčili, že učebné plány vcelku vyjadrujú novú štruktúre našej školy, že záujmové krúžky a doučovacie skupiny sú zjavným pokrokom proti starej škole, 5. za najväčší klad nášho výskumu pokladám i to, že sa učitelia vedome podujali kontrolovat'svoju prácu, zaznamenávat' jej priebeh, hodnotit' jej klady a dívat' sa na svoju prácu vo vzt'ahu k prostrediu, $k$ žiactvu a k rodičom žiakov, čo bude najzjavnejším prínosom zlepšenia vnútornej školskej práce. "SELECKÝ, Andrej: Výskum učebných osnov na I. a II. stupni všeobecnovzdelávacích škôl. In: Jednotná škola, roč. V., č. 1 - 2, 1949 - 1950, s. 31 - 32.

${ }_{96}$ „Z výskumu sme sa presvedčili, že aj v budúcnosti t'ažiskom našej práce zostane terajšia otázka č. 7 a 8, t. j. či je prevedený v učebných osnovách jednotlivých učebných predmetov 


\section{Pedagogické okrsky}

V prípade okrskov, o ktorých primárne vzdelávacej funkcii som sa už v predchádzajúcom texte zmienil, je dôležité vychádzat' z definície ich pôsobnosti. Nachádza sa v správe o okresných a krajských pedagogických zboroch pre 15. gremiálnu poradu PŠVU zo dňa 8. decembra 1950. Podl'a tohto prameňa: „V týchto okrskoch /úsekoch/ideologickými a pedagogickými prednáškami, ako aj vzornými praktickými výstupmi vykonávala sa prevýchova nášho učitel'stva pre prácu v socialistickej škole." ${ }^{\prime 97} \mathrm{Na}$ základe tohto dokumentu je možné hovorit’ o troch základných platformách činností realizovaných na pôde pedagogických okrskov: ideologické prednášky, pedagogické prednášky a praktické vzdelávanie. Tomuto členeniu v zásade zodpovedá obsah správ o činnosti OPS, ktoré boli systematicky publikované na stránkach Zvestí ŠPÚ. Napríklad plán OPS v Seredi pre všetky okrsky na školský rok 1949/1950 určil za hlavné aktivity riešenie problémov málotriednych škôl (pedagogický problém), žiacku samosprávu (pedagogický problém) a politické vzdelávanie učitel'ov. ${ }^{98} \mathrm{Na}$ otázku, akým spôsobom okrsky realizovali vzdelávanie pedagógov, začlenených do jednotlivých OPS, máme tak v zásade zodpovedanú. $\mathrm{V}$ tomto momente však bude zaujímavé priblížit' si jednotlivé formy činnosti okrskov o niečo podrobnejšie.

Niektoré z prednášok realizovali priamo pracovníci ŠPÚ - o ich prednáškovej činnosti na poli OPS (v nami sledovanom období) disponujeme presnými údajmi: $v$ školskom roku 1948/1949 OPS navštívilo 22 pracovníkov ŠPÚ, pričom zrealizovali 44 prednášok. ${ }^{99} \mathrm{~V}$ nasledujúcom školskom roku 1949/1950 sa počet ich návštev výrazne znížil: na poli OPS uskutočnilo 5 pracovníkov 19 prednášok. ${ }^{100}$ Na pôde OPS v Skalici bolo v rámci pripravovaných troch cyklov prednášok (13. január 1949, 10. február 1949, 10. marec 1949) plánované vystúpenie ôsmich odborných pracovníkov ŠPÚ, ktorí mali svojich poslucháčov oboznámit’ s aktuálnymi otázkami výchovy. ${ }^{101}$ Prítomnost' zástupcov ŠPÚ je doložená pri

správny výber učiva v náležitom rozsahu [...] “SELECKÝ, Andrej: Výskum učebných osnov na I. a II. stupni všeobecnovzdelávacích škôl, s. 32.

${ }^{97}$ SNA, Okresné a krajské pedagogické sbory. Referát priložený k materiálu týkajúcemu sa XV. gremiálnej porady PŠVU zo dňa 8. decembra 1950, s. 1.

98 Zo života a práce okresných pedagogických zborov na Slovensku. In: Zvesti Štátneho pedagogického ústavu v Bratislave. Príloha časopisu Jednotná škola. Bratislava : Štátne pedagogické nakladatel'stvo, III. - IV. štvrt'rok 1949, s. 40.

${ }_{99}$ SNA, Okresné a krajské pedagogické sbory. Referát priložený k materiálu týkajúcemu sa XV. gremiálnej porady PŠVU zo dňa 8. decembra 1950, s. 2.

100 SNA, Okresné a krajské pedagogické sbory. Referát priložený k materiálu týkajúcemu sa XV. gremiálnej porady PŠVU zo dňa 8. decembra 1950, s. 2.

101 Dňa 13. januára 1949 mali vystúpit': Eduard Oravský (Skúšanie a klasifikovanie žiactva), Ol'ga Styková (Požiadavky nových učebných osnov a učebnice škôl II. stupňa) a Jozef Bezák (Zmysel predškolskej výchovy). V druhom cykle (10. február 1949) mali odzniet' prednášky 
príležitosti založenia a „prvých krôčikov“ pedagogických zborov. Referent pre výskum učebných plánov a osnov na národných školách a výskum dobových učebníc Ján Ededy sa za ŠPÚ zúčastnil schôdze učitel'ov zo školských okresov Rimavská Sobota a Feledince (dnešné Jesenské), na ktorej bol založený miestny OPS ${ }^{102}$; na prvej plenárnej schôdzi OPS vo vtedajšom Turčianskom Svätom Martine dňa 26. februára 1948 „naznačil smernice vývinu pedagogickej teórie a praxe v l'udovodemokratickej škole, d'alej možnosti a spôsob spolupráce ŠPÚ a OPS, najmä pri hodnotení a vypracovaní vzorných učebníc, pri výskume žiactva a pri iných pedagogicko-didaktických otázkach. "103

Prednášky sledujúce problematiku „sociálne-politickej výchovy a školy v l'udovodemokratickom zriadení" tvorili síce nevyhnutnú súčast' činnosti okrskov, v každom prípade však predstavovali len čast' z celkovej náplne pôsobenia OPS. Zaujímavý prehl'ad politicky ladených tém, ktoré v danej dobe predstavovali „povinnú jazdu“ v rámci prednáškovej činnosti, nám ponúka noticka týkajúca sa OPS vo Vranove, kde v priebehu 2. štvrt'roka 1949 „na pedagogických konferenciách zapodievali sa otázkou československého školstva v socializme, socialistickou výchovou, novými osnovami a učebnicami a novým hospodárskym školstvom, sút’ažením na školách, prácou sovietskeho pedagóga Makarenka, priekopníctvom, významom priatel'stva ČSR - SSSR, vývinom l'udskej spoločnosti, otázkou kapitalizmu a socializmu, sút'ažením na školách. Vcelku bolo 16 ideologických a 26 pedagogických prednášok."104 Súčast'ou dobového politicko-spoločenského koloritu bolo aj prijímanie záväzkov - napríklad k príležitosti IX. zjazdu KSČ. 105

Ludovíta Bakoša (Aktuálne problémy pedagogiky), Karola Erdélskeho (O učebných pomôckach - s praktickými ukážkami) a Rudolfa Čiernika (Rodičovské združenie a žiacke organizácie). V tret'om cykle dňa 10. marca 1949 mali odzniet' prednášky Viliama Gaňa (Z oblasti defektológie) a Pavla Bernátha ( $O$ záujmových krúžkoch). Okrem týchto ôsmich prednášatel'ov z radov pracovníkov ŠPÚ v prvom cykle mali vystúpit’ d'alší dvaja autori, v druhom cykle taktiež dvaja, v tret'om cykle traja. Plánovanie po okresných pedagogických zboroch. Pozri viac: Okresný pedagogický zbor v Skalici. In: Zvesti Štátneho pedagogického ústavu $v$ Bratislave. Príloha časopisu Jednotná škola. Bratislava : Štátne pedagogické nakladatel'stvo, I. štvrt'rok 1949, s. 14.

$102 \mathrm{Z}$ činnosti OPS na Slovensku. 10. Rimavská Sobota. In: Zvesti Štátneho pedagogického ústavu v Bratislave. Príloha časopisu Jednotná škola. Bratislava : Štátne pedagogické nakladatel'stvo, II. polrok 1948, s. 17.

103 Z činnosti OPS na Slovensku. 15. Plenárna schôdzka OPS v Turč. Sv. Martine. In: Zvesti Štátneho pedagogického ústavu v Bratislave. Príloha časopisu Jednotná škola. Bratislava : Štátne pedagogické nakladatel'stvo, II. polrok 1948, s. 18.

104 Zo života okresných pedagogických zborov. Vranov. In: Zvesti Štátneho pedagogického ústavu v Bratislave. Príloha časopisu Jednotná škola. Bratislava : Štátne pedagogické nakladatel'stvo, II. štvrt'rok 1949, nečíslovaná zadná strana.

105 V Liptovskom Hrádku si v roku 1949 všetci učitelia vypracovali konkrétne záväzky, ktoré kontrolovala tzv. učitel'ská pät'ka (mala na starosti vykonávanie akčných plánov). 
V krátkych správach o pôsobení OPS sa nachádza množstvo zmienok o prednáškach zameraných na metodické otázky vyučovania a problémy školskej praxe. Z množiny prednášok metodickej proveniencie spomeniem podrobný rozpis pripravovaných vystúpení z OPS v Sabinove (program na školský rok 1948/1949), ktoré sa mali týkat' tém Štúdium nových učebných plánov, Nové učebné osnovy, Pedagogické princípy, Ako sa pripravujem na vyučovanie a podobne.106 Čo sa týka otázok školskej praxe, napríklad na pôde OPS v Topol'čanoch bola na konferenciách pozornost' venovaná doučovacím skupinám, záujmovým krúžkom, didaktickým zásadám, problematikou výchovy v puberte, „vnútornou náplňou kreslenia na národných školách a významom písania v elementárke“.107 Objavovali sa aj výstupy zamerané na prehlbovanie vedomostí ohl'adom jednotlivých vyučovacích predmetov. ${ }^{108}$ Prednášky úzko súviseli s následnými diskusiami, ktoré po poukázaní na konkrétne problémy a potreby mohli vyústit' do ustanovenia špecializovaných odborných pracovných komisií. ${ }^{109}$

Tretia dôležitá forma činnosti - praktické vzdelávanie - prebiehala vo forme návštev - hospitácií tzv. vzorového vyučovania. Vznikali tak príležitosti pre inšpiráciu a osvojenie si kvalitných a zároveň inovatívnych vyučovacích metód. Správa z OPS Brezno nad Hronom z 2. polroka 1948 vyzdvihuje istú učitel'ku A. Pekárovú, ktorá pre 5. ročník miestnej Štátnej l'udovej školy uskutočnila vzorové vyučovanie „o pokroku a vzdelanosti“, pričom „k svojej práci nazhromaždila A. Pekárová množstvo

\footnotetext{
„VŠetci učitelia si stanovili osobitné záväzky k IX. zjazdu KSČ."Zo života okresných pedagogických zborov. Liptovský Hrádok. In: Zvesti Štátneho pedagogického ústavu v Bratislave. Príloha časopisu Jednotná škola. Bratislava : Štátne pedagogické nakladatel'stvo, II. štvrt'rok 1949, nečíslovaná zadná strana.

106 Plánovanie po okresných pedagogických sboroch. Okresný pedagogický zbor v Sabinove. In: Zvesti Štátneho pedagogického ústavu v Bratislave. Príloha časopisu Jednotná škola. Bratislava : Štátne pedagogické nakladatel'stvo, I. štvrt'rok 1949, s. 13 - 14.

${ }_{107}$ Zo života okresných pedagogických zborov. Topol’čany. In: Zvesti Štátneho pedagogického ústavu v Bratislave. Príloha časopisu Jednotná škola. Bratislava : Štátne pedagogické nakladatel'stvo, II. štvrt'rok 1949, nečíslovaná zadná strana.

${ }^{108}$ Napríklad v rámci OPS Brezno nad Hronom si učitelia z breznianskeho okresu vypočuli prednášku O ciel’och fyzikálnej výučby v rámci vlastivedy. Z činnosti OPS na Slovensku. 1. Brezno n/Hronom. In: Zvesti Štátneho pedagogického ústavu v Bratislave. Príloha časopisu Jednotná škola. Bratislava : Štátne pedagogické nakladatel’stvo, II. polrok 1848, s. 16.

${ }^{109}$ Počas plenárnej schôdze OPS v Turčianskom Sv. Martine: „Živá a podnetná debata sa rozvinula o problémoch, vyplývajúcich zo zjednotenia nižších tried gymnázia a meštianskej školy a to najmä o vplyve na vyučovanie a prospech stredných škôl vyšších. Pre skúmanie týchto otázok utvorila sa komisia, ktorá na poradách OPS, kde sa stretajú profesori i učitelia, bude riešit' spoluprácu medzi školami I., II. a III. stupňa. " Z činnosti OPS na Slovensku. 15. Plenárna schôdzka OPS v Turč. Sv. Martine. In: Zvesti Štátneho pedagogického ústavu v Bratislave. Príloha časopisu Jednotná škola. Bratislava : Štátne pedagogické nakladatel'stvo, II. polrok 1948, s. 18.
} 
pomôcok: celú malú národopisnú výstavku, žiacke ručné práce, l'udové výšivky, keramiku, obrazový materiál, knihy, modely obydlia atd'. Žiačky v jej triede mali samosprávu, vzorne vedenú a pracovné zošity, do ktorých si zapisovali nielen preberané učivo, ale ho dopíñali aj svojimi vlastnými poznámkami a ilustráciami." $110 \mathrm{~V}$ už spomínanom pláne pracovného programu na školský rok 1948/1949 pre OPS v Sabinove sú zachytené presne stanovené mená učitel'ov a obsah vzorových, resp. praktických vyučovaní, ktoré mali dotyční pedagógovia viest' na materských a národných školách. ${ }^{111} \mathrm{~V}$ Turčianskom Svätom Martine boli hospitácie konané v sídlach okrskových porád. ${ }^{112}$ OPS pre učitel'ov organizovali aj exkurzie do škôl.113

Na záver by som sa chcel ešte zmienit' o špecifických aktivitách OPS, ktoré boli vyvíjané nielen podl'a povinných smerníc, ale do určitej miery aj z vlastnej iniciatívy jednotlivých pedagogických zborov. Konkrétne môžem takto hovorit' o obnovovaní okresnej učitel'skej knižnice v Sobranciach ${ }^{114}$, o testovaní žiakov na všetkých prešovských školách na konci školského roka 1947/1948 pod kuratelou miestneho OPS ${ }^{115}$, o redigovaní školskej rubriky „Škola a učitel“" v denníku Ciel' (OPS Turčiansky Svätý Martin) ${ }^{116}$, o bábkovom divadelníctve na školách ${ }^{117}$ alebo

${ }^{110} \mathrm{Z}$ činnosti OPS na Slovensku. 1. Brezno n/Hronom. In: Zvesti Štátneho pedagogického ústavu v Bratislave. Príloha časopisu Jednotná škola. Bratislava : Štátne pedagogické nakladatel'stvo, II. polrok 1848, s. 16.

111 Plánovanie po okresných pedagogických sboroch. Okresný pedagogický zbor v Sabinove. In: Zvesti Štátneho pedagogického ústavu v Bratislave. Príloha časopisu Jednotná škola. Bratislava : Štátne pedagogické nakladatel'stvo, I. štvrt'rok 1949, s. 13 - 14.

112 Zo života okresných pedagogických zborov. Turč. Sv. Martin. In: Zvesti Štátneho pedagogického ústavu v Bratislave. Príloha časopisu Jednotná škola. Bratislava : Štátne pedagogické nakladatel'stvo, II. štvrt'rok 1949, nečíslovaná zadná strana.

113 OPS v Skalici plánoval na 9. december 1948 exkurziu učitel’ov materských a národných škôl na materské a pokusné národné školy vo východomoravskom Zlíne. Plánovanie po okresných pedagogických zboroch. Okresný pedagogický zbor v Skalici. In: Zvesti Štátneho pedagogického ústavu v Bratislave. Príloha časopisu Jednotná škola. Bratislava : Štátne pedagogické nakladatel'stvo, I. štvrt'rok 1949, s. 14.

114 Z činnosti OPS na Slovensku. Sobrance. In: Zvesti Štátneho pedagogického ústavu v Bratislave. Príloha časopisu Jednotná škola. Bratislava : Štátne pedagogické nakladatel’stvo, I. polrok 1948, s. 22.

$115 \mathrm{Z}$ činnosti OPS na Slovensku. 7. Prešov. In: Zvesti Štátneho pedagogického ústavu v Bratislave. Príloha časopisu Jednotná škola. Bratislava : Štátne pedagogické nakladatel'stvo, II. polrok 1948, s. 16.

${ }^{116}$ Zo života okresných pedagogických zborov. Turč. Sv. Martin. In: Zvesti Štátneho pedagogického ústavu v Bratislave. Príloha časopisu Jednotná škola. Bratislava : Štátne pedagogické nakladatel'stvo, II. štvrt'rok 1949, nečíslovaná zadná strana.

${ }^{117}$ V rámci OPS Levice sa jeho členovia v rámci okresu venovali bábkovému divadelníctvu na školách a zakladali mládežnícke aj učitel'ské spevokoly. Zo života a práce okresných pedagogických zborov na Slovensku. OPS v Leviciach. In: Zvesti Štátneho pedagogického ústavu v Bratislave. Príloha časopisu Jednotná škola. Bratislava : Štátne pedagogické nakladatel'stvo, III. - IV. štvrt'rok 1949, s. 39. 
o fungovaní okresného učitel'ského spevokolu v Hlohovci, ktorý po prvýkrát vystúpil v roku 1949 pri príležitosti 32. výročia Vel'kej októbrovej socialistickej revolúcie. ${ }^{118}$

\section{ZÁVER}

V rámci predloženého textu som primárne hl'adal odpoved' na otázku, ktorými konkrétnymi spôsobmi ŠPÚ usmerňoval činnost' pedagógov združených v okresných a od roku 1950 aj krajských pedagogických zboroch. ŠPÚ stanovoval vedecko-výskumné úlohy, ktorými sa mali primárne zaoberat' odborné pracovné komisie v rámci pedagogických zborov, pričom počítal aj s vlastnou iniciatívnou učitel'ov. ŠPÚ v zásade pripravil metodické východiská, pedagogické zbory výskum prakticky zrealizovali a nimi zostavený materiál s výskumnými výsledkami následne ŠPÚ zhodnotil a spracoval do finálnej vedeckej podoby. Verejnú komunikáciu smerom z ŠPÚ k pedagogickým zborom zabezpečovala príloha časopisu „Jednotná škola“ Zvesti ŠPÚ, na stránkach ktorej okrem praktických pokynov, výskumných zadaní a výziev na zapojenie pedagógov pracovníci ŠPÚ taktiež publikovali odborné texty slúžiace na prehĺbenie pochopenia pedagogickej teórie a praxe. Povinnost'ou pedagogických zborov bolo v pravidelných intervaloch ŠPÚ informovat' o aktuálne uskutočňovaných aktivitách. Na pôde okrskov pedagogických zborov pracovníci ŠPÚ členskú základňu OPS vzdelávali a informovali prostredníctvom prednášok.

Ak by som mal celú uvedenú problematiku stručne zhrnút', ŠPÚ v tejto sfére svojej činnosti rozvíjal dve vzájomne sa silno prepletajúce línie: rozvoj pedagogickej teórie a praxe a súčasne ideologizácia dobovej pedagogickej vedy. V prípade riadenia pedagogických zborov môžeme hovorit' nielen o snahe zvyšovat' úroveň metodiky vyučovania v teoretickej a v praktickej rovine, ale aj o systematickej implementácii sovietskej pedagogiky v jej výrazne dogmatickej podobe, ktorá bola pre obdobie stalinizmu typická.

Predložené premýšl'anie si vzhl'adom na pomerne úzky rozsah síce nemôže robit' nárok na vyčerpávajúcu úplnost', predstavuje však podnet na hlbší výskum jednotlivých aspektov činnosti Štátneho pedagogického ústavu. Na záver mi ostáva dodat', že text poukázal na zložitost' a nejednoznačnost' vývoja povojnového slovenského školstva, ktoré nie je možné hodnotit’ v zjednodušujúcom čiernobielom podaní.

\footnotetext{
118 Zo života a práce okresných pedagogických zborov na Slovensku. OPS v Hlohovci. In: Zvesti Štátneho pedagogického ústavu v Bratislave. Príloha časopisu Jednotná škola. Bratislava : Štátne pedagogické nakladatel’stvo, III. - IV. štvrt'rok 1949, s. 39.
} 